\title{
Cardioprotective Pathways During Reperfusion: Focus on Redox Signaling and Other Modalities of Cell Signaling
}

\author{
Pasquale Pagliaro, Francesca Moro, Francesca Tullio, Maria-Giulia Perrelli, and Claudia Penna
}

\begin{abstract}
Post-ischemic reperfusion may result in reactive oxygen species (ROS) generation, reduced availability of nitric oxide $\left(\mathrm{NO}^{*}\right), \mathrm{Ca}^{2+}$ overload, prolonged opening of mitochondrial permeability transition pore, and other processes contributing to cell death, myocardial infarction, stunning, and arrhythmias. With the discovery of the preconditioning and postconditioning phenomena, reperfusion injury has been appreciated as a reality from which protection is feasible, especially with postconditioning, which is under the control of physicians. Potentially cooperative protective signaling cascades are recruited by both pre- and postconditioning. In these pathways, phosphorylative/ dephosphorylative processes are widely represented. However, cardioprotective modalities of signal transduction also include redox signaling by ROS, S-nitrosylation by NO* and derivative, S-sulfhydration by hydrogen sulfide, and O-linked glycosylation with beta-N-acetylglucosamine. All these modalities can interact and regulate an entire pathway, thus influencing each other. For instance, enzymes can be phosphorylated and/or nitrosylated in specific and/or different site(s) with consequent increase or decrease of their specific activity. The cardioprotective signaling pathways are thought to converge on mitochondria, and various mitochondrial proteins have been identified as targets of these post-transitional modifications in both pre- and postconditioning. Antioxid. Redox Signal. 14, 833-850.
\end{abstract}

\section{Introduction}

A CUTE CORONARY ARTERY DISEASES are the leading cause of mortality and morbidity in Western countries. Cardiological practice has changed rapidly over the last few years, progressing from thrombolysis to direct coronary intervention and stenting to rapidly restore myocardial blood flow. It is generally accepted that whenever possible a short door-toballoon time limits infarct size, ventricular dysfunction, and major cardiac adverse events (MACE), and, consequently, improves prognosis $(68,109,120,202)$. Therefore, it is no doubt that early reperfusion is the "gold standard" therapy for acute myocardial infarction. In fact, these strategies have had a major impact on improving outcomes. However, we have also come to understand that reperfusion itself is, paradoxically, an important cause of organ damage $(68,109,202)$. Starting almost immediately after the restoration of blood flow, a cascade of adverse events (see below) triggers a vicious cycle leading to additional injury and cell death. Local and more widespread inflammatory responses will concur to increase the extent of infarction in otherwise viable tissue. This acceleration of damages after reperfusion led to the concept of myocardial reperfusion injury $(3,21,68,109,156,177,202)$.

\section{Myocardial Reperfusion Injury Is Due to Complex Mechanisms}

Reperfusion injury is due to mechanisms involving mechanical, extracellular, and intracellular processes. The pathogenesis of reperfusion injury has been reviewed elsewhere (21, $53,151,156,202,207)$ and is beyond the aim of the present review. However, a short description of the principal events of the processes involved in reperfusion injury may be useful for the reader. Schematically, acute reperfusion injury can be due to the following interconnected key mechanisms: a) reactive oxygen and nitrogen species (ROS/RNS) generation; b) reduced availability of nitric oxide ( $\left.\mathrm{NO}^{*}\right)$; c) $\mathrm{Ca}^{2+}$ overload; and d) mitochondrial permeability transition pore (mPTP) opening (Fig. 1).

These mechanisms may lead to cell death and to the activation of the $\mathrm{NF} \kappa \mathrm{B}$ and other transcription factors, which, in turn, lead to the augmented expression of molecules of cellular adhesion, leukocyte infiltration, and no-reflow phenomenon, which exacerbate tissue injury (see reviews 137, 177, 183, 201, 202, 207).

\section{Reactive oxygen and nitrogen species generation}

Reactive oxygen species (ROS) is a collective name for a group of oxygen-containing species such as superoxide anion

Department of Clinical and Biological Sciences, University of Turin, Orbassano, Italy. 


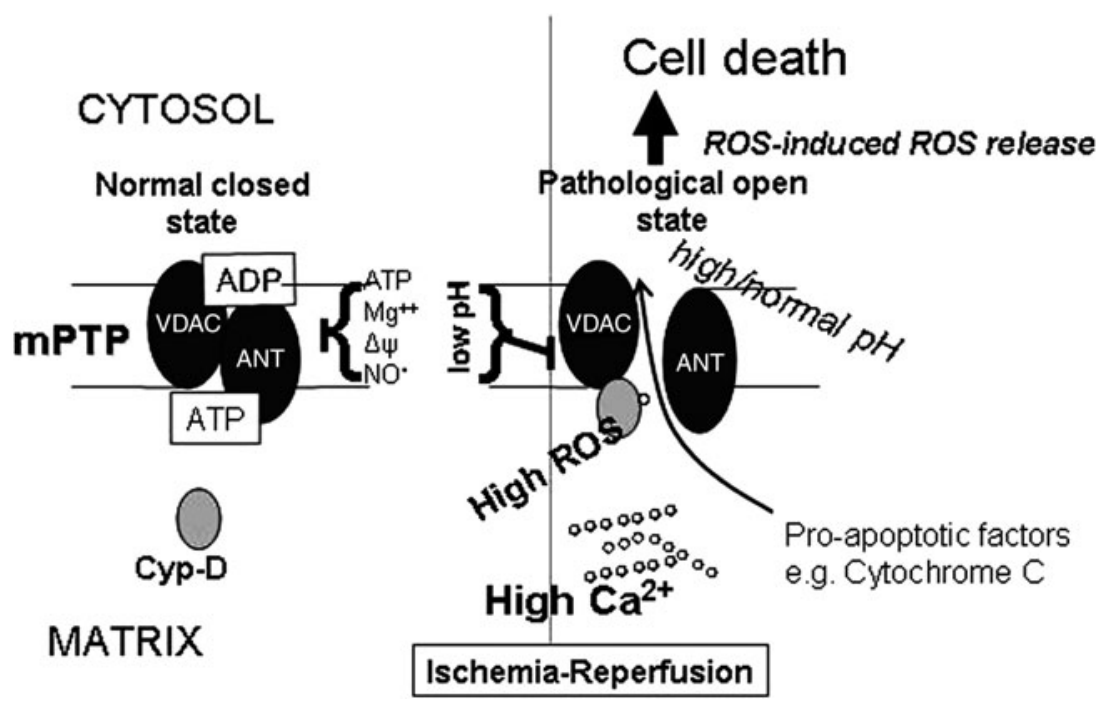

FIG. 1. Mitochondrial permeability transition pore (mPTP) is believed to be composed of the adenine nucleotide translocase (ANT) in the inner membrane, the voltage-dependent anion channel (VDAC) of the outer membrane, and cyclophilin D (Cyp-D) in the matrix. $\mathrm{Ca}^{2+}$ overload occurring during ischemia should bring mitochondria closer to the threshold at which mPTP opening takes place, favoring the occurrence of prolonged mPTP opening during reperfusion, a phenomenon described as mitochondrial priming. $\mathrm{MPTP}$ opening hardly occurs during ischemia, because it is strongly inhibited by acidosis. mPTP opening during reperfusion may be due to $\mathrm{Ca}^{2+}$ overload, which may stimulate the interaction of Cyp-D with other mPTP component(s), which triggers permeability transition. In fact,

typically they open in reperfusion when $\mathrm{Ca}^{2+}$ overload, generation of reactive oxygen species (ROS), and pH normalization occur. Their opening leads to cell death through the release of pro-apoptotic factors and via ROS-induced ROS release. The dashed vertical line represents the passage from ischemia (low $\mathrm{pH}$ ) to reperfusion ( $\mathrm{pH}$ normalization).

radical $\left(\mathrm{O}_{2}^{-\bullet}\right)$, hydrogen peroxide $\left(\mathrm{H}_{2} \mathrm{O}_{2}\right)$, and hydroxyl radical $\left(\mathrm{OH}^{\bullet}\right)$. Reactive nitrogen species (RNS) refers to the family of compounds derived from $\mathrm{NO}^{*}$, the signaling molecule synthesized from L-arginine by the nitric oxide synthases (NOSs, i.e., neuronal, endothelial, and inducible NOS). $\mathrm{NO}^{*}$ can also be converted, by oxidation or reduction, into many chemically reactive forms including nitrogen dioxide radicals $\left(\mathrm{NO}_{2}{ }^{\circ}\right)$, peroxynitrite $\left(\mathrm{ONOO}^{-}\right)$, and nitroxyl $(\mathrm{HNO})$, each of which yields distinct functional consequences $(11,12,55,138$, $142,164,198)$. The implications of the biological balance between $\mathrm{NO}^{\circ}$ and oxidative stress have been examined in detail in several recent reviews $(12,55,112,138,164,198)$.

Various deleterious processes can be the result of an imbalance between the excess formation of ROS and/or RNS and limited antioxidant defenses (referred to as 'oxidative stress'). For instance, ROS indiscriminately react with lipids, proteins, and DNA. These are complex processes: in brief, ROS reaction with lipids gives rise to peroxyl and alkoxyl radicals leading to lipid peroxidation; reaction with amino acid residue side chains of proteins form protein carbonyls, and reaction with methionine forms methionine sulfide; reaction with DNA may oxidize DNA bases such as 8-OhdG, leading to mutation and DNA strand breaking $(1,12,187,204$, 208-212). Excessive ROS/RNS production is considered deleterious to cell function and mitochondria, where they act as inducers of mPTP opening (see below). Alternatively, low levels of reactive species may act as secondary messengers, modulating signalling pathways by covalent modification of target molecules (referred to as 'redox signaling', see also below).

Oxidative stress related to the massive generation of ROS/RNS may play an important role in reperfusion injury $(1,12,187,204,208-212)$. At reperfusion, $\mathrm{O}_{2}^{-\bullet}$ and other ROS may strongly oxidize the cardiomyocytes already damaged by the ischemia, thus favoring cell death $(1,2,53,116,183$, 184). Moreover, in reperfusion, $\mathrm{O}_{2}{ }^{-}$may react with $\mathrm{NO}^{\circ}$, forming $\mathrm{ONOO}^{-}$. Therefore, $\mathrm{ONOO}^{-}$, may represent a sign of a reduced availability of $\mathrm{NO}^{\bullet}$ and it may participate with $\mathrm{O}_{2}^{-} \cdot$ in myocardial injury $(10-12,52,135,165)$. In particular, high $\mathrm{ONOO}^{-}$concentrations are considered to be highly cytotoxic $(11,12,135,165)$. Peroxynitrite cytotoxicity is also due to its reaction with proteins (on tyrosine and thiol groups), lipids, and DNA $(11,12,21,135,159)$. For instance, peroxynitrite inactivates prostacyclin synthase by tyrosine nitration, playing a crucial role in the pathophysiology of the cardiovascular system (211). The contribution of high levels of $\mathrm{ONOO}^{-}$to myocardial and vascular dysfunction during ischemia and reperfusion, and other cardiovascular pathologies has recently been reviewed $(53,135)$.

Although the sources of ROS and RNS within the cells are many, in cardiomyocytes the main sources are mitochondria $(38-41,142)$. It has been suggested that for massive ROS release the involvement of MPTP is required. Zorov et al. (209) "triggered" massive ROS release in isolated cardiomyocytes via intracellular photoactivation of tetramethylrhodamine compounds. These triggered-ROS were associated with mitochondrial depolarization, along with prolonged $\mathrm{MPTP}$ opening and a consequent large burst of ROS from mitochondria. Thus, a positive feedback loop of "ROS-induced ROS release" has been suggested $(209,210)$. These organelles may also produce a large quantity of ROS from monoamine oxidase and p66Shc activity (39-41). Even NOSs can become "uncoupled", resulting in the generation of $\mathrm{O}_{2}{ }^{-\bullet}$ and $\mathrm{OH}^{\bullet}$ instead of $\mathrm{NO}^{\bullet}$ under certain conditions such as scarcity or absence of the cofactor, tetrahydrobiopterin, and/or of the substrate, L-arginine, as well as in the presence of oxidation of the $\mathrm{Zn}^{2+}$-thiolate center of NOS homodimer. NOS catalytic activity becomes "uncoupled" when the coupling between the reductase domain and L-arginine oxidation at the active site is lost and electron transfer from NADPH through the flavins (FAD and FMN) to $\mathrm{O}_{2}$ is not inhibited, resulting, in fact, in a formation of $\mathrm{O}_{2}^{-}$and/or $\mathrm{OH}^{\bullet}$ (212).

Cells may defend against excessive ROS by intracellular antioxidants, including $\mathrm{NO}^{\circ}$, and by the coordinated activity of scavenging enzymes. In particular, $\mathrm{O}_{2}{ }^{-\bullet}$ is transformed into $\mathrm{H}_{2} \mathrm{O}_{2}$ by superoxide dismutase (SOD) isoenzymes. However, 
since in the presence of $\mathrm{Fe}^{2+}$ or $\mathrm{Cu}^{2+}$, the $\mathrm{H}_{2} \mathrm{O}_{2}$ can be transformed into $\mathrm{OH}^{\cdot}$, which may be more toxic than $\mathrm{O}_{2}{ }^{-}$and $\mathrm{H}_{2} \mathrm{O}_{2}$, an increase in toxicity can occur. Yet, $\mathrm{O}_{2}{ }^{-\bullet}$ itself may trigger the release of $\mathrm{Fe}^{2+}$ from $\mathrm{Fe}^{3+}$-complexes (Haber-Weiss cycle). Therefore, $\mathrm{O}_{2}{ }^{-\bullet}$ can be directly and selectively deleterious and/or it can be deleterious via its transformation into $\mathrm{OH}^{*}$. As the flux of $\mathrm{O}_{2}{ }^{-}$exceeds the one of $\mathrm{NO}^{*}$, cellular damage may develop induced by one-electron oxidations caused by nitrogen dioxide and by the Fenton reaction (188). $\mathrm{O}_{2}^{-\cdot}$ can also be transformed into $\mathrm{ONOO}^{-}$, whose cytotoxicity can be reduced by the addition of $\mathrm{NO}^{*}$ via a secondary reaction due to the antioxidant properties of $\mathrm{NO}^{\circ}$ and formation of nitrosating species in this process $(34,52,164)$. Yet the threat of $\mathrm{OH}^{*}$ can be avoided by the fact that $\mathrm{H}_{2} \mathrm{O}_{2}$ can be quickly reduced to water by several enzymes (catalase, glutathione peroxidase, and peroxiredoxins). It can, then, be argued that during reperfusion a limited formation of $\mathrm{H}_{2} \mathrm{O}_{2}$ may be protective if $\mathrm{NO}^{*}$ is adequately formed or added to reduce $\mathrm{ONOO}^{-}$cytotoxicity, via a secondary reaction, thus avoiding $\mathrm{MPTP}$ opening. This is in line with the observation that strategies to increase NO ${ }^{\bullet}$ bioavailability (e.g., by nitrite infusion (157)) in reperfusion are very often protective (e.g., Refs. 169, 178-180) and is in line with the concept that when properly regulated ROS/RNS are not purely destructive (52), but rather engage an important cellular signaling function (see below, Redox signaling by ROS and RNS).

\section{Reduced availability of nitric oxide}

It is well known that $\mathrm{NO}^{\circ}$ can modify proteins via different chemical processes. Actually, NO* exerts many of its physiological effects via the formation of complex (or coordinating) bonds with the transition metal ions of heme groups $(94,142$, 198). This kind of reaction is the basis for the activation of classical vasodilatation, through a pathway wherein $\mathrm{NO}^{*}$ binds to soluble guanylate cyclase, thereby stimulating the formation of cyclic GMP (cGMP) from GTP. Subsequently, cGMP activates protein kinase $G$, which mediates many of the actions of NO* It has been reported that physiological levels of NO* inhibit mPTP opening with an $\mathrm{IC}_{50}$ of $11 \mathrm{nM}$ (19). As said, when under pathological conditions $\mathrm{NO}^{\bullet}$ production is not sufficient or it is supraphysiological this results in deleterious effects.

Clearly many of the pathological processes correlated to reduced availability of $\mathrm{NO}^{\bullet}$ are due to the reduction of cGMPdependent effects. However, nitration of tyrosine by RNS (not to be confused with nitrosylation, see below) may also play a role (34). In fact, as reported above, under pathological conditions $\mathrm{NO}^{\bullet}$ reacting with $\mathrm{O}_{2}^{-}$can be just enough to form $\mathrm{ONOO}^{-}$. Thus, peroxynitrite can react directly and irreversibly with proteins, lipids, and DNA, a result that is frequently deleterious (21). For instance, $\mathrm{ONOO}^{-}$irreversibly blocks the mitochondrial respiratory chain $(108,119)$. In fact, $\mathrm{ONOO}^{-}$ reacts with sulfhydryl groups and iron-sulfur clusters in respiratory complexes, and induces nitration/oxidation of MnSOD, further augmenting mitochondrial oxidative stress in a vicious cycle (158).Yet, as said, when NO* is sufficiently produced, $\mathrm{ONOO}^{-}$cytotoxicity can be reduced via a secondary reaction(164). $\mathrm{NO}^{*}$ deficiency can also cause vasoconstriction and formation of micro-thrombi into the lumen of the small vessels $(1,162,169)$. These mechanisms, combined with the adhesion of the leucocytes to the endothelium, in- duced by ROS, can lead to the "no-reflow phenomenon" (1, 162). As a consequence, $\mathrm{NO}^{\bullet}$ deficiency and free radicals also have downstream effects, resulting in the initiation and progression of a highly orchestrated acute inflammatory response through the release of cytokines, activation of vascular endothelial cells and leukocytes with expression of cell surface adhesion molecules. Upregulation of a program of proinflammatory genes will contribute to the onset and maintenance of post-ischemic inflammation $(162,163)$.

\section{$\mathrm{Ca}^{2+}$ overload}

In normoxia, $\mathrm{Ca}^{2+}$ acts at several levels within the mitochondria to stimulate ATP synthesis, and these organelles can be considered a major player in $\mathrm{Ca}^{2+}$ buffering. In fact, to generate a proton gradient across the inner membrane, $\mathrm{Ca}^{2+}$ uptake occurs in mitochondria that utilize oxygen (38-41). The cytosolic $\mathrm{Ca}^{2+}$ overload starts during ischemia and is further increased during reperfusion. In fact, the oxidative stress depresses $\mathrm{Ca}^{2+}$ regulatory mechanisms. Altered $\mathrm{Ca}^{2+}$ handling during ischemia induces structural fragility and excessive contractile activation upon reperfusion. The $\mathrm{Ca}^{2+}$ overload also activates calcium-dependent proteases, which could partially degrade contractile proteins. These effects are the basis of a progressive increase of ventricular diastolic pressure (hypercontracture), myocardial stunning, and contraction band necrosis $(100,151,170) . \mathrm{Ca}^{2+}$ overload favors the expression of proapoptotic elements from mitochondria (208) and increases the cellular osmolarity, favoring explosive swelling of cardiomyocytes. $\mathrm{Ca}^{2+}$ overload may also occur within mitochondria where it is considered to be responsible for the prolonged opening of $\mathrm{mPTP}$, which is considered the point of "no-return" leading to cell death (see below and Refs. 38-41, 66) Actually, mitochondrial $\mathrm{Ca}^{2+}$ overload can lead to enhanced generation of ROS, prolonged MPTP opening, rupture of the outer mitochondrial membranes (OMM) due to swelling, and cytochrome $\mathrm{c}$ release, thus leading to cell death $(8,32)$. The interplay between cytosolic $\mathrm{Ca}^{2+}$ and mitochondria is analyzed in more detail in other reviews of this Forum $(14,39,84)$.

\section{Mitochondrial permeability transition pore opening}

The $M P T P$ is a nonspecific megachannel of the mitochondrial membrane whose prolonged opening in the first few minutes of myocardial reperfusion promotes cell death $(4,8$, $30,32,58,60,64,69-72,105)$. We should, however, keep in mind that mPTP opens and closes all the time and that a transient increase in opening probability of the pores may be involved in ROS-dependent cardioprotection by preconditioning $(72,105)$.

mPTP has been proposed to be formed by adenine nucleotide translocase (ANT), the voltage-dependent anion channel (VDAC), and cyclophilin-D (Fig.1) (38-41). Besides being the moment of "no-return" for cell death in reperfusion, mPTP opening is also involved in heart failure development $(17,58$, $127,196)$. The oxidative opening of MPTP is central in reperfusion injury (for reviews, see $38-41,158$ ), and, as said, it causes mitochondrial depolarization, loss of small molecular weight substances from the matrix, and rupture of OMM (6, $32,126,196)$. However, experiments with transgenic mice in each of the putative components of mPTP reached controversial results. In fact, neither gene deletion nor knockdown of 
VDAC nor ANT prevents $\mathrm{mPTP}$ opening in response to mitochondrial $\mathrm{Ca}^{2+}$ overload $(6,9,27,97,126)$. The intriguing possibility that cyclophilin-D has a role in regulating apoptotic proteins in a manner that is independent of the $\mathrm{MPTP}$ has been suggested (46). Nevertheless, in transgenic mice sustained modulation of a mitochondrial function may alter cardiac development and functions not related to the response to acute ischemia. Pharmacological tools to study the roles of $\mathrm{mPTP}$ in acute ischemia/reperfusion scenario are available, and could be applied clinically as therapeutic agents for ischemic heart disease $(57-60,86)$. In fact, selective targeting of drugs designed to modulate mitochondrial function and genomics for therapeutic benefit are made possible by recent advances in mitochondrial biology (for reviews, see Refs. 22, 86). More details on the central role of mPTP opening in protection and reperfusion injury are given by other reviews in this Forum $(14,29,39)$.

In summary, conditions occurring during ischemia and reperfusion, such as $\mathrm{Ca}^{2+}$ overload, ROS, inorganic phosphate and mitochondrial depolarization favor prolonged mPTP opening (Fig.1). These factors are counteracted by physiological mPTP antagonists, such as increased mitochondrial membrane potential, low $\mathrm{pH}$, magnesium ions, ADP, and nitric oxide $(14,39,84)$.

In reperfusion, cell death can occur by apoptosis, oncosis/necrosis, and autophagy (see the following for extensive review on this topic (e.g., Refs. 122, 134, 181)). However, autophagy is not simply a destructive phenomenon, but in certain conditions autophagy can be considered a protective mechanism against I/R injury (for reviews, see Refs. $62,155)$. Besides irreversible injury leading to cell death and myocardial infarction, reperfusion injury of the heart is characterized by reversible contractile dysfunction (stunning), endothelial dysfunction, microvascular damage, and reperfusion arrhythmias. All these deleterious events can be prevented by both pre- and postconditioning (190).

\section{Preconditioning and Postconditioning}

In 1986, Murry et al. (123) reported that four $5 \mathrm{~min}$ circumflex occlusions, each separated by $5 \mathrm{~min}$ of reperfusion, followed by a sustained $40 \mathrm{~min}$ occlusion (index-ischemia) dramatically attenuated $I / R$ injury in the dog heart. This phenomenon was named ischemic preconditioning (PreC). In 2003, Zhao et al. (207) reported that three episodes of $30 \mathrm{sec}$ of reperfusion $/ 30 \mathrm{sec}$ of ischemia performed immediately after index-ischemia (60 min coronary occlusion) in the dog heart dramatically attenuated reperfusion injury. This phenomenon was named postconditioning (PostC). The protective effects observed with PostC are comparable to those observed with the powerful PreC $(109,113,207)$. In fact, PostC may reduce apoptosis, necrosis, and endothelial dysfunction/activation, thus leading to a reduced endothelia/leukocyte interaction and to a reduced ROS inflammatory formation. A reduced incidence of reperfusion arrhythmias has been also observed (56, $96,125)$. Notable, already by 1994 Grech and Ramsdale (63) had reported that intermittent reperfusion may restore sinus rhythm. Whether PostC protects from myocardial stunning is still controversial $(148,172)$. These protective effects are discussed in the review of Vinten-Johansen et al. (190).

PostC, first described in dogs, was subsequently demonstrated in other species, and can also be recruited clinically in human patients to reduce infarct size $(59,73,86,140,176)$. Notably in humans, PostC has long-term protective effects (86). The infarct size reduction by ischemic PostC depends on duration of the index-ischemia, on the number and duration of the brief re-occlusions, and/or on the presence of comorbidities $(81,148,174)$. Further studies should resolve the difference in efficacy of PostC between experimental models and human subjects with comorbidities and/or aging $(40,149$, 155, 190).

Besides passive effects attributed to modification of hemodynamics during PostC maneuvers, the cardioprotection triggered by PostC is attributed to active effects that are mediated by several signaling pathways $(77,139-141,144,147$, 191). The link between passive and active effects is not clear, but during initial reperfusion Post $C$ delays, the post-ischemic recovery of intracellular $\mathrm{pH}$, and the ability to trigger the activation of biochemical pathways and to limit infarct size might depend on this $\mathrm{pH}$ effect [see below and Inserte et al. (84)]. Potentially, in these activated pathways, variations of protein structures/activities occur via different post-translational modifications, namely phosphorylation, dephosphorylation, O-linked glycosylation, S-nitrosylation, and sulfhydration (see below, Modalities of cell signaling in cardioprotection). In this review we will focus on these mechanisms of cardioprotection with emphasis to redox-signaling to reduce reperfusion injury.

Before analyzing these mechanisms, it is necessary to review a brief description of the main cardioprotective pathways involved in pre- and postconditioning, which have been described in several recent publications $(59,68,71,140,146$, 201). Also in this Forum up-to-date, aspects of the pathways involved in PostC are reported (e.g., 29, 70).

\section{Cardioprotective Pathways}

It is now thought that, after a triggering phase in preischemic period, the actual protection by PreC occurs in the reperfusion rather than ischemic phase with the repopulation of sensitized G-protein coupled receptor (GPCR) at the beginning of myocardial reperfusion following the indexischemia. Thus, pre and postconditioning activate cardioprotective pathways that are protective against reperfusion injury. A schematic representation of these cardioprotective signal transduction pathways is reported in Figure 2.

Both PreC and PostC engage GPCR and enzymes that converge on the MPTP. However, subtle differences are present in the pathways and in cell signaling at different times and different species (14-16, 29, 70, 77, 173). GPCR agonists include adenosine, bradykinin, and opioids, with a possible sensitization of relevant receptors by prior ischemias. The exact subtypes of adenosine, opioids, and bradykinin receptors involved in triggering protection are still a matter of controversy $(29,142)$. We have shown a role for endogenous bradykinin in PostC via $B_{2}$-bradykinin receptor activation $(141,144,200)$. A role for these receptors in PostC has been confirmed in other models, including a knockout mice model $(142,200)$. Receptor tyrosine kinases may also be involved, possibly via the epidermal growth factor receptor transactivation to activate PI3K/Akt. The activation of PKC can be downstream of Akt or, especially in the triggering phase, can be achieved via phospholipase signaling with adenosine receptor agonism $(65,73,134,201)$. For the aims of the current 
FIG. 2. Schematic representation of cardioprotective pathways (Reperfusion Injury Salvage Kinases (RISK) pathway and Survivor Activating Factor Enhancement (SAFE) pathway). Posttranslational modifications of proteins occur both in the cytosol and in organelles, particularly within mitochondria in which specific targets are recognized. ADE (adenosine), OP (opioids), TNF $\alpha$ (tumor necrosis factor alpha), PLC (phospholipase C), and PLD (phospholipase D), BK (bradykinin), EGF (epidermal growth factor); other acronyms as in the text. Persistent acidosis during early reperfusion, activation of RISK and SAFE pathways, and the activation of other cell signaling lead to cardioprotection, where the prevention of mPTP opening plays a central role. Reactive oxygen and nitrogen species (ROS/RNS) with signaling role may affect other cell signaling. Although sulfhydration and glycosylation may occur in reperfusion, they are not reported in ischemic postconditioning. STAT3 is a transcription factor and thus nuclear effects are expected. Yet, it has also direct effects on mitochondria (see review by Hausenloy et al. (70) in this Forum). For further explanation, see text.

\section{Cardioprotective pathways}

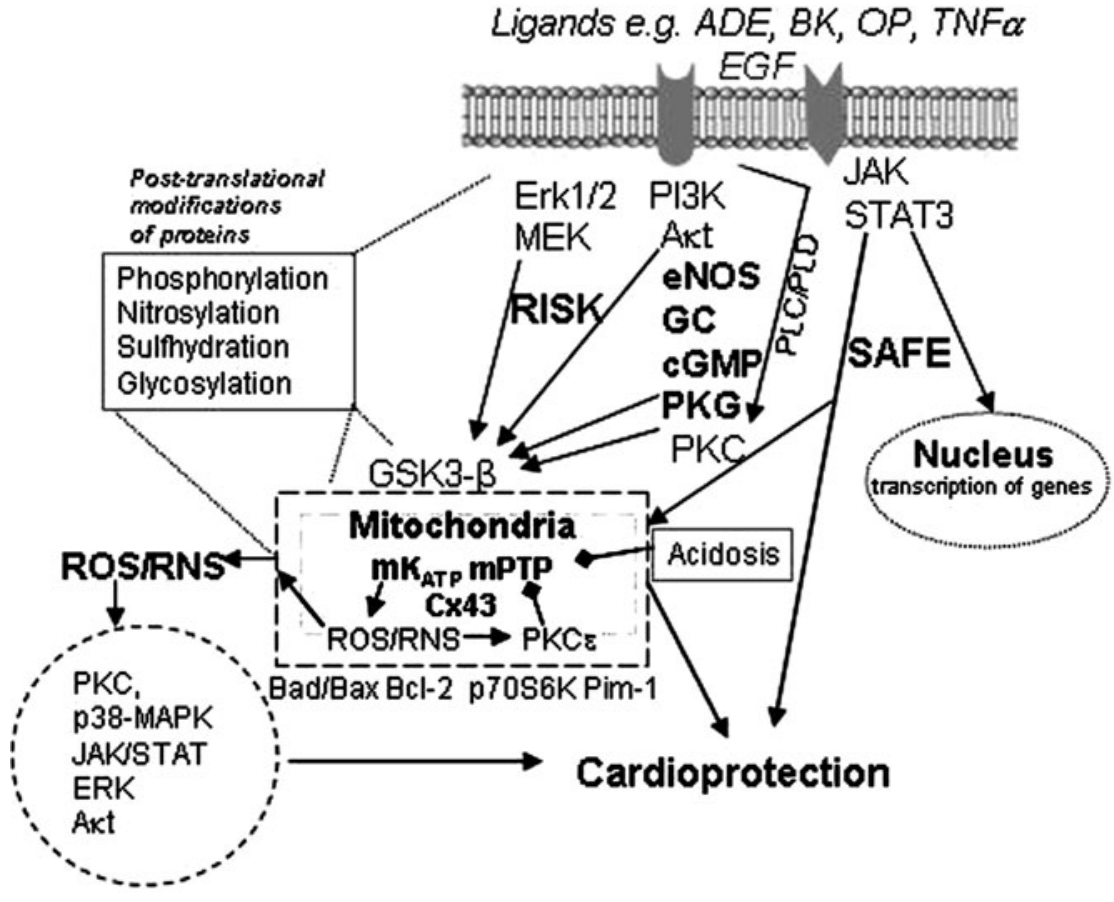

review, the involvement of tyrosine kinases is particularly intriguing since these kinases are activated by low doses of hydrogen peroxide limiting reperfusion injury (166).

Collectively three major pathways are recognized: the cGMP/PKG-pathway, the Reperfusion Injury Salvage Kinases (RISK) pathway and Survivor Activating Factor Enhancement (SAFE) pathway (65-73, 102, 139-144, 147, 191, 206) (Fig.2). RISK includes the phosphorylation of Akt, ERK1/2, p70S6K, and NOS. SAFE pathway includes JAK and STAT-3 phosphorylation, and both pathways may converge on mitochondria via GSK-3 $\beta$, which is suggested to be among the end-effectors for the cardioprotection by ischemic PostC $(70-72,185)$. Other proteins regulating apoptosis, such as Bad/Bax, Bcl-2, and Pim-1, are also correlated with cardioprotection via prevention of $\mathrm{MPTP}$ opening and reduction of mitochondrial swelling. Overall, various protective mechanisms seem to converge on $\mathrm{mPTP}(72,142,146)$. Contextually other enzymatic (phosphorylation and O-linked glycosylation) and nonenzymatic (nitrosylation and sulfhydration) intracellular signaling may involve multiple targets, which converge on organelles, particularly mitochondria, which are considered critical events leading to protection $(26,70,139$ $144,167,186)$. These pathways and intracellular signaling are not mutually exclusive and are recruited by both pre- and postconditioning to a different extent, depending on a plethora of factors. In this perspective it is particularly intriguing that VDAC, constituent of the MPTP, may be also a target for O-linked glycosylation (see below). Therefore, apart from cGMP/PKG, RISK, and SAFE pathways, there are redox mechanisms and events that may be considered alternative or cooperative to the classical pathways. Of note, the importance of RISK has been recently questioned, and its relevance in larger mammals seems to be severely limited; from a trans- lational point of view these animal models may be more suitable $(76,131,173)$. Concerns and controversies about the possibilities of translating the results of animal experiments into human clinical trials have recently been discussed by van der Worp et al. (189). Nevertheless, preliminary clinical data indicate that drugs targeting RISK may confer a benefit to patients with acute myocardial infarction over and above that provided by myocardial reperfusion alone (70), but they remain to be confirmed in large-scale clinical studies. These features are also considered by Ivanes et al. (86) and by Vinten-Johansen et al. (190) in the present Forum.

\section{Interaction Between Redox Environment and Cardioprotective Pathways}

ROS/RNS with a signaling role are suggested to be formed during three time points: during preconditioning-ischemia and/or during reperfusion that follows the brief preconditioning-ischemia, as well as in pre and postconditioning during the initial part of reperfusion that follows the indexischemia (Fig. 3) (30,73, 142).

The origin of these protective reactive species can be many, including mitochondria, in which $\mathrm{K}^{+} \mathrm{ATP}\left(\mathrm{mK}_{\mathrm{ATP}}\right)$ channels, which are considered targets of protective cascades $(14,142$, $161,168,201)$, may play a pivotal role. In fact, it has been suggested that $\mathrm{mK}_{\mathrm{ATP}}$ channel activation leads to alkalinization of the mitochondrial matrix and generation of ROS/RNS with a protective signaling role $(33,142,168,201)$. It has also been suggested that $\mathrm{NO}$ donors activate $\mathrm{mK}_{\mathrm{ATP}}$ channels in rabbit ventricular myocytes and potentiate the protective effect of $\mathrm{mK}_{\mathrm{ATP}}$ opener diazoxide (168). However, controversy exists on the nature, existence, and opening of $\mathrm{mK}_{\mathrm{ATP}}$ channels, which may also be a toxic process $(33,36)$. Nevertheless, 

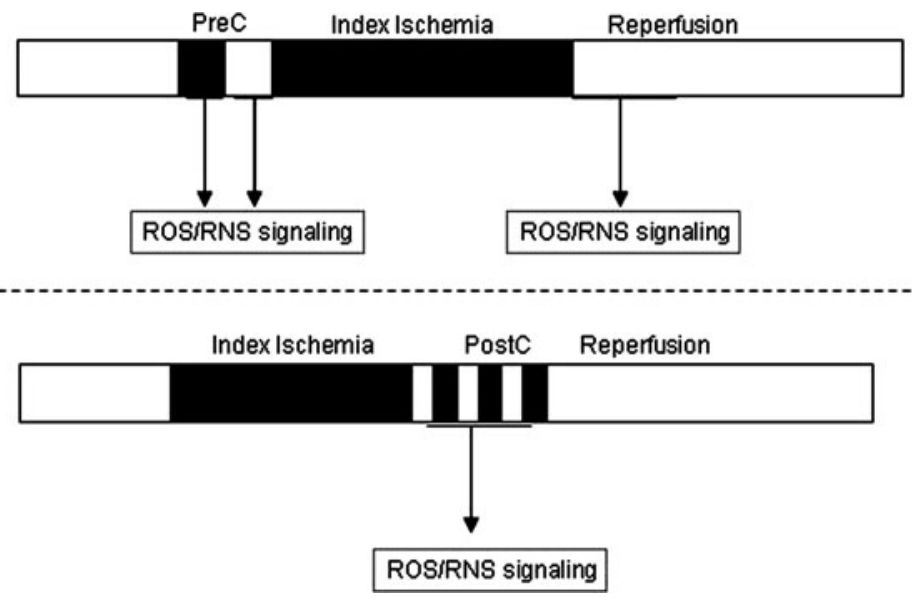

FIG. 3. Reactive oxygen and nitrogen species (ROS/RNS) with signaling role have been described during brief preconditioning ischemia, during reperfusion following the brief preconditioning ischemia, as well as during early reperfusion which follows the index-ischemia, both in preconditioning (PreC) and postconditioning (PostC). it has been suggested that besides channel phosphorylation, $\mathrm{mK}_{\text {ATP }}$ can be opened by $\mathrm{NO}^{\bullet}$ and derivative (nitrosylation) as well as by sulfhydration (see below). Moreover, mitochondrial connexin- 43 has also been implicated in ROS signaling although its role is not completely defined (14-16). A target of ROS in redox signaling is the PKC (possibly PKC 22 ); in fact hearts can be preconditioned by simply infusing free radicals into the coronary arteries and that protection can be blocked by a PKC antagonist (184). Indeed, it has been reported that ROS can activate PKC in vitro by reacting with thiol groups associated with the zinc finger region of the molecule (98). RNS-dependent activation of PKC, possibly via redox-sensible nitrosylation process, has been also suggested $(161,180)$. Actually, PreC via ROS/RNS formation leads to a decreased intracellular reduced glutathione (GSH) pool, which may stabilize S-nitrosothiol formation by attenuating GSH-mediated trans-/denitrosylation, thus potentiating redox signaling and converting death-signal into survivalsignal $(161,167)$.

Although PKC plays a pivotal role in cardioprotection, PKC location in the signaling cascade is unclear $(69,70)$. Yet the regulation and role of $\mathrm{PKC}$ is still debated, with a possible role for directly activated PKC, together with possible PKGdependent phosphorylation of mitochondrial $\mathrm{PKC} \varepsilon$, which in turn inhibits $\mathrm{mPTP}$ opening via ROS signaling $(57,201)$.

Generation of ROS/RNS, distal to $\mathrm{mK}_{\mathrm{ATP}}$ opening, may also trigger activation of kinases additional to PKC, including p38-MAPK and JAK/STAT $(15,70,73,201)$. The involvement of p38-MAPK and JNK in preconditioning was also reported for angiotensin-II and summarized in the recent review by Daiber (33). Besides kinase activation, the increased phosphorylation may also be the result of the well-known inhibitor effect of ROS on phosphatases (for review, see Ref. 24).

We and other authors have shown that ROS scavengers such as $\mathrm{N}$-acetyl-cysteine (NAC) and $\mathrm{N}$-(2-mercaptopropionyl)glycine (MPG) given during the PostC maneuvers prevented the protective effects $(43,142,150,186)$. These scavengers given in the first few minutes of myocardial reperfusion following the index-ischemia also prevent PreC-protection (73). Variations of the activity of endogenous antioxidant enzymes in early reperfusion may also play an important role in PostC protection (150). Another mechanism in both pre- and postconditioning involves the persistence of intracellular acidosis during early reperfusion $(30,54,73,83,86)$. In fact, while acidosis prevents
mPTP-opening, the reintroduction of $\mathrm{O}_{2}$ at the beginning of reperfusion may allow ROS signaling to activate protective cascades. These may also prevent the reactivation of mitochondrial enzymes able to produce massive quantity of ROS. Of note, acidosis is also responsible of nonenzymatic $\mathrm{NO}^{\circ}$ formation (213), which has been suggested to be involved in PostC-triggering (142).

Ultimately, the $\mathrm{mPTP}$-opening during early reperfusion is inhibited by many of the above reported effects. In particular, persistent acidosis during early reperfusion may play a pivotal role, contributing to the limitation of mPTP-opening and additionally favoring enzymatic and/or nonenzymatic mechanisms of protection. Therefore, it can be argued that phosphorylative processes and/or other modalities of signal transduction (e.g., S-nitrosylation, S-sulfhydration, and Olinked glycosylation) are recruited by both pre- and postconditioning to a different extent to achieve protection via mitochondrial salvage.

Importantly, the cardioprotection by pre- and postconditioning can be mimicked pharmacologically by the administration of endogenous ligands, such as adenosine, bradykinin, or opioids, and by agents that act on mitochondria such as diazoxide $(141,142,144)$. Particularly intriguing is the protective role of cyclosporine $\mathrm{A}$, an inhibitor of mPTPopening, which has recently been used in humans during reperfusion as a PostC agent $(59,86)$. It is also of note that redox-sensitive cardioprotective effects can be induced by nitroglycerin $(31,44)$ and by nitrite infusion (157).

\section{Modalities of Cell Signaling in Cardioprotection}

Cellular signaling or signal transduction pathways represent a common property of viable cells, which include signals starting from enzymes, cyclic nucleotides, calcium, and even gases such as carbon monoxide, hydrogen sulfide $\left(\mathrm{H}_{2} \mathrm{~S}\right)$, and $\mathrm{NO}^{\circ}$. Although protein phosphorylation is the most widely studied form of signal transduction, as above mentioned, there are many other post-translational modifications of proteins (e.g., acetylation, glycosylation, glutathionylation, methylation, nitration, nitrosylation, and ubiquitylation) (35, $79,88,92)$. As said, some of these "additional" modalities of signal transduction have been described in the ischemia/ reperfusion scenario and have already shown their importance in cardioprotection. Of course, these include redox 
signaling in which ROS/RNS modify proteins in a meaningful way, including $S$-nitrosylation by $\mathrm{NO}^{*}$ and derivative. $S$-sulfhydration by $\mathrm{H}_{2} \mathrm{~S}$ is also gaining ground as a cellular signaling process in cardioprotection. Other interesting signaling systems that are still poorly understood are O-linked glycosylation, which involves the linkage of beta-Nacetylglucosamine through an oxygen atom to proteins at their serine and threonine residues $(23,42,105,106,130)$. Theoretically, all these modalities are not limited to interactions with specific enzymes but rather act to regulate an entire pathway influencing each other. For instance, an enzyme can be phosphorylated and/or nitrosylated in a specific and/or different site(s) with consequent increase or decrease of its specific activity. Despite this interplay, for clearness sake, in the following part we will consider singularly the most relevant cellular signaling in cardioprotection (i.e., those enzymatic-mediated: phosphorylation and O-linked glycosylation, and those nonenzymatic-mediated: redox signaling, including S-nitrosylation and S-sulfhydration). Whenever possible, interactions among these signaling processes are outlined. Of course, each of these processes has been extensively reviewed elsewhere $(21,35,79,80,87,88,90,98,180,193)$; therefore here they are briefly analyzed with particular attention to the cardioprotective mechanisms.

\section{Enzyme-Mediated Post-Translational Modifications in Cardioprotection}

\section{Phosphorylation}

The processes of phosphorylation of proteins as regulatory modalities in the cell have been known since the early 1950 s (20). In ischemia/reperfusion and cardioprotection, a plethora of kinases and phosphatases are involved (see above and Refs. 14, 29, 70, 190). Processes of phosphorylation/dephosphorylation occur on the cell membrane, in the cytosol, and in organelles (Fig. 4). In particular in the mitochondria, which are considered the final target of cardioprotective pathways (14), phosphorylation/dephosphorylation occurs on the external face of the OMM, in the intermembrane mitochondrial space (IMS), and in the mitochondrial inner membrane (MIM) and matrix.

As said, RISK and SAFE pathways consider phosphorylative cascades outside mitochondria (70, 71, 102, 185). Sphingosine-1-phosphate (S1P), which plays a pivotal role in cytoskeletal rearrangement and apoptosis, also seems necessary for successful preconditioning. Recently it has been shown that sphingosine kinase-1, the key enzyme catalyzing the formation of S1P, is critical for cardioprotection by PostC (89). Apart from the phosphorylative events in the cell membrane and cytosol, converging lines of evidence support that pathways converge on mitochondria, where phosphorylation has an impressive impact on cardioprotection. Therefore, here we focus on phosphorylation within mitochondria in the cardioprotective scenario [The role of mitochondrial function in Pre and PostC is reviewed in other articles of the present Forum $(14,39)]$.

On the external face of the OMM, there are several intracellular receptors (scaffolds), which serve as sites for the integration of signals for different processes (i.e., apoptosis, cytoprotection, energetic demand, fission, and steroidogenesis) (175). Among scaffolds, we consider the PKA anchoring proteins (199), and the PKC-interacting proteins (152) RICKs
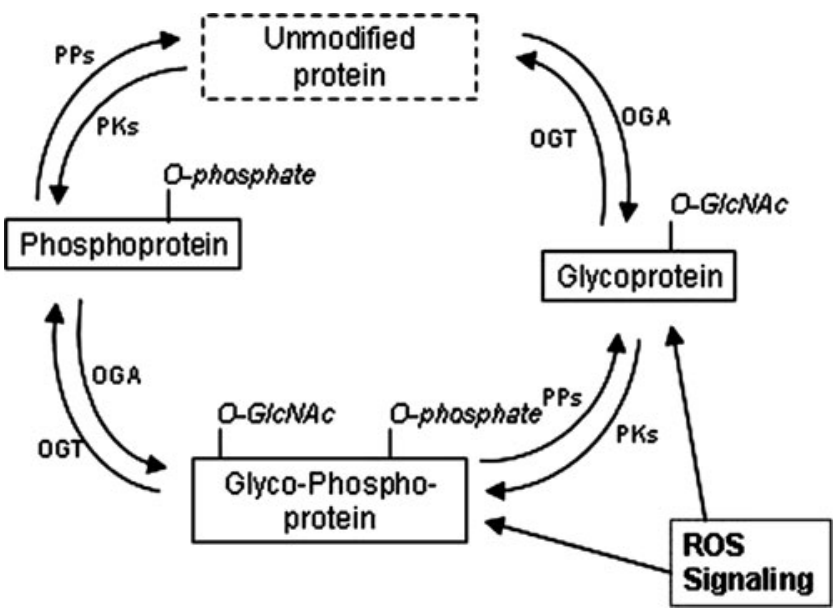

FIG. 4. Proteins can be O-linked glycosylated (O-linked glycosylation, O-GlcNAc) and/or phosphorylated, and the adjacent $\mathrm{O}-\mathrm{GlcNAc}$ and/or phosphorylation can influence the addition of either moiety. An increase in the production of mitochondrial reactive oxygen species (ROS) with signaling role may be accompanied by an increase in O-GlcNAc. Uridine-diphospho-N-acetylglucosamine: polypeptide $\beta$-N-acetylglucosaminyltransferase (OGT); $\mathrm{N}$ acetylglucosaminidase (OGA); Protein kinases (PKs); Protein phosphatases (PPs). See text for further explanation.

and RACKs (i.e., the receptors for inactive/active kinases, respectively) (118). For instance, both $\mathrm{PKC} \delta$ and $\mathrm{PKC} \varepsilon$ mitochondrial translocation have been seen to be involved in ischemia/reperfusion injury and cardioprotection, respectively (28). Studies with cardiomyocytes have shown that inhibitors of the PKC-RACK interaction abolish cardioprotection against ischemia/reperfusion (25) as well as the associated phosphorylation of mitochondrial targets (132). PKC $\varepsilon$ translocates to the mitochondria where it phosphorylates VDAC with consequent inhibition of the $\operatorname{mPTP}(7,73)$. Yet, mitochondrial PKC $\varepsilon$ was found in complexes with MAP kinases. Formation of these complexes correlates with phosphorylation/inactivation of the pro-apoptotic protein $\operatorname{BAD}(8,205)$. PKA can also link to the OMM through one of the PKA anchoring protein (D-AKAP1) (67). Aside from several isoforms of PKC and PKA, other kinases that have been shown to undergo translocation to the OMM include GSK-3 $\beta$, Raf kinases, and ERKs. In particular, ERK1/2 may associate with the OMM in a complex with $\mathrm{PKC} \varepsilon$, though their substrates have not been defined (8). It has also been suggested that signalosomes (scaffolded caveolins containing enzymes) triggered by cardioprotective ligands converge on OMM to activate $\mathrm{mK}_{\mathrm{ATP}}$ and to prevent $\mathrm{mPTP}$-opening (57).

In the IMS, principal targets for phosphorylation are mainly involved in bioenergetics and apoptosis. These processes are particularly relevant in cardioprotective mechanisms. The majority of phosphorylation in the IMS appears to be on tyrosine residues. Given their location, phosphorylation of these tyrosines might be predicted to influence nucleotide transport (104). For instance, phosphorylation of ANT (component of $\mathrm{mPTP}$ ) at its Tyr194 has been found in rat hearts either pre- or postconditioned with isofluorane (51). Aside the IMS-facing cavity of ANT, other important proteins of the IMS have emerged as phosphoproteins, including cytochrome c, 
creatine kinase, and Ser 115/116 of subunit I, as well as sites within matrix-facing subunits IV and $\mathrm{Vb}$ (50). In studies of myocardial I/R injury, hypoxia reduced complex IV function coincidentally with hyperphosphorylation (Ser, Thr, and Tyr residues) of several subunits on complex IV, including subunit 1 . Complex IV activity could be rescued by PKA inhibitors $(74,155)$.

In the MIM and matrix, proteins fall into several functional categories, including energy metabolism/oxidativephosphorylation, lipid metabolism, and redox enzymes; frequent targets are pyruvate dehydrogenase complex, branched chain dehydrogenase, $\mathrm{F}_{1} \mathrm{~F}_{0} \mathrm{ATPase}$, and complex I. In the context of cardioprotection, pharmacological pre- and postconditioning with either adenosine or diazoxide led to phosphorylation of many mitochondrial proteins. Studies suggested at least five phosphorylation sites on the $\beta$ subunit of the $\mathrm{F}_{1} \mathrm{~F}_{0} \mathrm{ATPase}(94)$. Inhibition of $\mathrm{F}_{1} \mathrm{~F}_{0} \mathrm{ATPase}$ activity may be a feature of the preconditioned heart, thus reducing ATP consumption by reverse mode of the enzyme (145). In the MIM of subsarcolemmal mitochondria, the phosphorylated portion of connexin-43, which plays an important role in ROS formation, increases with ischemia and decreases with PostC $(16,146)$. From proteomic studies it appears that there are more mitochondrial phosphoproteins than previously thought, particularly within the matrix and on the matrixfacing proteins of the inner mitochondrial membrane (78, 136), further supporting that phosphorylative processes occur within the mitochondria $(57,142)$. Therefore, our better understanding of mitochondrial phosphorylation will also be of benefit for a future better understanding of the cardioprotective phenomena.

\section{O-linked glycosylation (O-GlcNAcylation)}

There are two basic types of glycosylation that occur on either asparagines (N-linked) or serines and threonines (O-linked) residue of proteins. Linkage of beta- $\mathrm{N}$ acetylglucosamine through an oxygen atom (O-linked) to proteins appears to be the most relevant in cardioprotection. While phosphorylation is determined by a plethora of enzymes, O-linked glycosylation is controlled by two enzymes, a transferase that attaches the sugar group (uridine-diphospho-N-acetylglucosamine:polypeptide $\beta$-Nacetylglucosaminyltransferase, OGT) and a hexosaminidase that removes it (beta-N-acetylglucosaminidase, OGA) (Fig. 4). It has been observed that ROS may increase flux through the hexosamine biosynthetic pathway, resulting in greater O-GlcNacylation of proteins $(101,160)$.

On several proteins, O-GlcNAcylation and O-phosphate alternatively occupy the same or adjacent sites (the "yin-yang phenomenon"), leading to the hypothesis that one function of this sugar group is to transiently block phosphorylation (197). Due to the importance of phosphorylation in cardiac protection, one can speculate that O-GlcNAcylation may interfere with protection. However, Champattanachai et al. (23) demonstrated in isolated neonatal rat ventricular myocytes that an inhibitor of OGT markedly reduced O-GlcNAcylation levels and exacerbated I/R injury. The authors suggested that increased O-GlcNAcylation levels may attenuate I/R induced $\mathrm{Ca}^{2+}$ overload and that activation of metabolic pathways leading to an increase in O-GlcNAcylation levels is an endogenous stress-activated response that improves cell sur- vival. It has been shown that glutamine-induced protection of isolated rat heart from I/R injury is mediated via increased protein O-GlcNAcylation levels (107). In particular, 30-min pretreatment with glutamine significantly improved cardiac functional recovery and decreased cardiac troponin-I release during reperfusion. This cardioprotection has been attributed to elevated levels of O-GlcNAcylation on nucleo-cytoplasmic proteins. Ngoh et al. (129) have shown in isolated cardiomyocytes subjected to hypoxia/reoxygenation that elevated expression of OGA reduced O-GlcNAcylation levels and augmented post-hypoxic cell death. Yet, short interfering RNA directed against OGA, as well as pharmacological inhibition of this hexosaminidase, significantly augmented O-GlcNAcylation levels and reduced hypoxia/reoxygenation cell death. Intriguingly, Ngoh et al. $(129,130)$ showed that the mitochondrial VDAC is also a target for O-GlcNAcylation modification and that the inhibition of OGA activity improves, whereas augmentation impairs, mitochondrial membrane potential recovery.

It should be emphasized that the interplay between these two post-translational modifications of proteins is not always reciprocal; rather a cross-talk between phosphorylation and O-GlcNAcylation signaling exists. For example, some proteins can be concomitantly O-GlcNAcylated and phosphorylated, and the adjacent O-GlcNAc or phosphorylation can regulate the addition of either moiety (Fig. 4). Other proteins, such as GSK-3 $\beta$, have multiple and distinct phosphorylation/O-GlcNAcylation sites on the same protein. Interestingly, phosphorylation/inhibition of GSK-3 $\beta$, which is protective, increased O-GlcNAcylation of 10 proteins, but decreased O-GlcNAcylation of 19 proteins (195). Conversely, increasing global O-GlcNAcylation levels by OGA inhibition resulted in a decrease in phosphorylation at about $33 \%$ of sites and an increase in phosphorylation at about $18 \%$ of sites (194). These studies clearly demonstrate nonreciprocal interplay between O-GlcNAcylation and phosphorylation and indicate the possibility for cooperativity between these types of cell signaling.

A cross-talk between redox and O-GlcNAcylation signaling has also been described (101). This may have a strong relevance in cardioprotection; in fact an increase in mitochondrial ROS production may be accompanied by an increase in O-GlcNAcylation (Fig. 4) (45), which, in turn, leads to an increase in O-GlcNAcylation of mitochondrial proteins and increased tolerance of mitochondria to stress. Some evidence indicates a potential mitochondrial isoform of OGT (93, $128,130,131)$. Moreover, it has been reported that augmentation of O-GlcNAcylation levels in cardiomyocytes attenuates $\mathrm{H}_{2} \mathrm{O}_{2}$-induced loss of mitochondrial membrane potential $(23,93,128,131)$ and that this may be due to O-GlcNAcylation of mitochondrial proteins such as VDAC. All these studies suggest that ROS from mitochondria contribute to the regulation of O-GlcNAcylation of proteins, which could, in turn, modulate the mitochondria response to oxidative-stress. Of course to establish the real role of O-GlcNAcylation in the contest of cardioprotection will require much more research. For instance, though O-GlcNAcylation variations have been observed in reperfusion, to the best of our knowledge, nobody has studied the role of O-linked glycosylation in PostC. Finally, it must be pointed out that although acute O-GlcNAcylation is beneficial, chronic O-GlcNAcylation may promote myocardial apoptosis (160). 


\section{Nonenzymatic-Mediated Post-Translational Modifications in Cardioprotection}

\section{Redox signaling by ROS and RNS}

When properly regulated under physiological conditions, both ROS and RNS are not purely destructive, but rather engage in important signaling functions both in and outside of mitochondria. Collectively with redox signaling, we consider the fact that proteins may undergo reversible chemical changes in response to changes in local redox potential. The ROS-induced cellular responses include precise molecular signals (modifications of cellular redox state) and their transduction into the organelles and the nucleus (compartmentalization), which modifies their (patho)-physiological role with a consequent influence on functions such as resistance to stress, senescence, and programmed cell death.

Here we focus on the oxidative processes (oxidation) of proteins, and in particular, on the modification of the cysteine thiol by incorporation of a $\mathrm{NO}^{\bullet}$ moiety to a sulfur atom to form the S-NO bond (S-nitrosylation). Since it has been suggested that nitric oxide is a weak S-nitrosating agent, it is likely that to yield S-nitrosothiols an incorporation of $\mathrm{NO}^{+}$ (nitrosyl cation) occurs. At high concentrations in oxygenated solutions, $\mathrm{NO}^{*}$ may mediate S-nitrosylation via $\mathrm{N}_{2} \mathrm{O}_{3}$ formation by the autoxidation of $\mathrm{NO}^{*}$ to nitrogen dioxide radicals and subsequent reaction with another $\mathrm{NO}^{\circ}$. The instantaneous redox state and ultrastructural accessibility of cysteine residue(s) under low-oxygen tension, such as hypoxia and ischemia, might determine whether a particular thiol in a given protein is subjected to S-nitrosylation (167).

As said, low amounts of ROS generated during brief periods of ischemia/reperfusion or given in lieu of brief periods of ischemia/reperfusion have been reported to be responsible for preconditioning-triggering $(48,183,184)$. The necessity of ROS signaling was demonstrated by both inducing PreC with ROS generators and avoiding PreC with ROS-scavengers given before the index-ischemia. Also, many G-proteincoupled receptor activators trigger preconditioning-like protection via ROS-dependent mechanisms, which may include PKC activation (71, 73, 121, 122, 142, 198, 201, 202).

We were the first to consider that ROS could also be included among the triggers of PostC. In fact, as said, large spectrum ROS scavengers such as NAC and/or MPG given during the Post $\mathrm{C}$ maneuvers prevented the protective effects $(43,142,147,186)$. Yet, we have been unable to reproduce cardioprotection with ROS generation by purine/xanthine oxidase given at reperfusion (141). Since ROS scavengers, given at the beginning of reperfusion, abolished both pre- and postconditioning-induced protection $(72,141,153,186)$, it is likely that the type, the concentration, and/or the compartmentalization of reactive species may play a pivotal role in triggering protection at reperfusion time. We can not exclude that a different ROS generator could trigger PostC protection (142). Postconditioning increased cardiac 3-nitrotyrosine concentration (a marker for $\mathrm{ONOO}^{-}$formation) after $5 \mathrm{~min}$ of reperfusion in normal but not in cholesterol-fed rats. Thus, early increase in $\mathrm{ONOO}^{-}$after PostC may play a role in PostCprotection (99). However, hyperlipidemia enhances preischemic levels of $\mathrm{ONOO}^{-}(133)$, but alters the PostC-induced $\mathrm{ONOO}^{-}$formation and blocks the protective effect (99). Furthermore, Iliodromitis et al. (81) and Wang et al. (192) suggest that PostC may reduce $\mathrm{ONOO}^{-}$formation. In particular, Ilio- dromitis et al. (81) report that PostC reduces myocardial and circulating levels of 3-nitrotyrosine after $10 \mathrm{~min}$ of reperfusion in the normal, but not in the hyperlipidemic rabbits. We have shown in rat hearts that, after $7 \mathrm{~min}$ of reperfusion, PostC induces an increase in S-nitrosylation of proteins and a reduction in 3-nitrotyrosine levels (150). To reconcile these apparent opposing results $(81,99,150,192)$ we can speculate that after an initial increase in $\mathrm{ONOO}^{-}$, a further increase in $\mathrm{NO}^{\circ}$ (via enzymatic and nonenzymatic processes (213)) can lead to the formation of $\mathrm{N}_{2} \mathrm{O}_{3}$, thus lowering $\mathrm{ONOO}^{-}$level and increasing S-nitrosylation (see also below). In fact, a decrease in $\mathrm{ONOO}^{-}$levels in the presence of excess $\mathrm{NO}^{-}$may be due to the secondary chemical interactions occurring between $\mathrm{NO}^{\bullet}$ and $\mathrm{ONOO}^{-}$(164). Many different endogenous enzymes regulate the intra-tissue homeostasis of ROS, including SOD and catalase (142, and references therein). We found that PostC discretely changes the activity of these enzymes in early reperfusion, decreasing SOD and increasing catalase activity (150). These effects might shift reactions towards RNS formation and may have impact on S-nitrosylation thus reducing injury due to oxidative-stress (see below and Figs. 5 and 6).

In this context, the sulfhydryl chemistry of cysteine residues within proteins represent peculiar targets, as they can adopt multiple oxidation states (75). In fact, cysteines can react with ROS/RNS to yield a number of species including intra- and intermolecular disulfide bonds (disulfide crosslinking), S-nitrosylated proteins, or the formation of mixed disulfides with glutathione (glutathionylation) (Fig.5) $(79,87)$. For instance, oxidation/nitrosylation/glutathionylation also represents intra-mitochondrial redox signals. In fact, experiments have shown that low concentrations of $\mathrm{H}_{2} \mathrm{O}_{2}$ and $\mathrm{S}$-nitroso-N-acetylpenicillamine cause redox modification of a selected group of mitochondrial proteins, despite little change

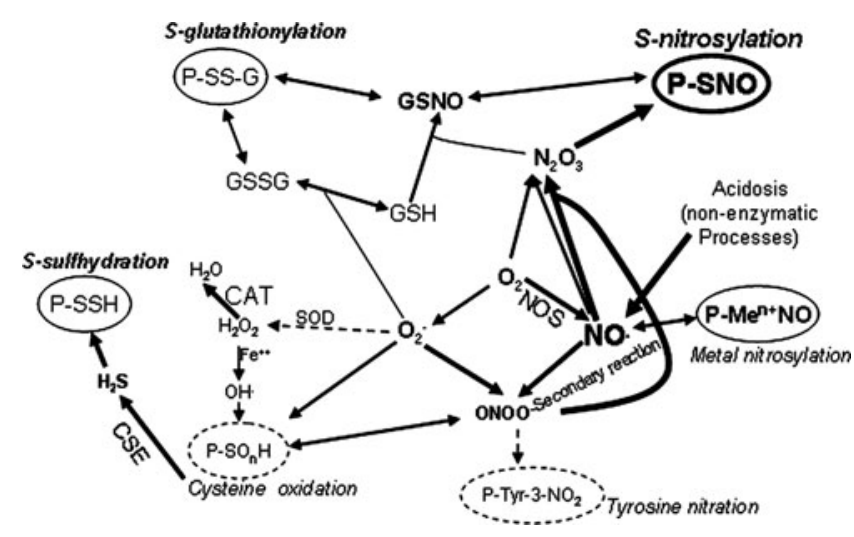

FIG. 5. Chemical relationship among different reactive oxygen species (ROS), reactive nitrogen species (RNS), and hydrogen sulfide $\left(\mathrm{H}_{2} \mathrm{~S}\right)$, and their impact on some posttranslational modification of proteins. The processes, the enzyme activities, and the reactions increased by postconditioning (PostC) are in thick bold lines, those decreased by PostC are in dashed/thin lines. In the excess of $\mathrm{NO}^{\circ}$, the secondary reaction between $\mathrm{ONOO}^{-}$and $\mathrm{NO}^{-}$may favor S-nitrosylation. $\mathrm{H}_{2} \mathrm{~S}$ physiologically produced by CSE from cysteine, induces S-sulfhydration of proteins. GSH, glutathione; GSSG, glutathione disulfide; GSNO, Snitrosoglutathione. See text for further explanation and other acronyms. 


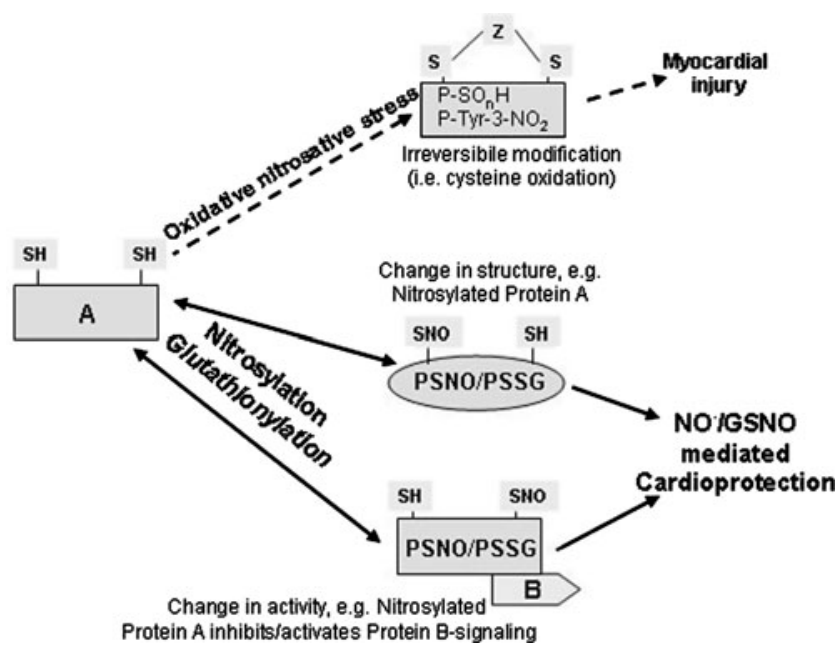

FIG. 6. Nitrosylation and glutathionylation are reversible post-translational protein modification leading to protection; oxidative/nitrosative stress may lead to irreversible modifications of protein which leads to damages. See also Figure 5.

in the redox status of the global mitochondrial thiol pool (79). Several of these proteins were recognized as redox-modified in response to endogenous mitochondrial ROS formation. Proteins targeted included pyruvate-dehydrogenase-kinase-2 and propionyl-CoA-carboxylase, among others. Both enzymes were inhibited by oxidation and could be reactivated by reduction with dithiothreitol (DTT). It can be inferred that, though many mitochondrial proteins can be thiol-modified under oxidative-stress, only a small subset of these modifications can be considered a real physiological/reversible redox signal and that the primary distinction between them would appear to be site-specific. In this context, S-nitrosylation and glutathionylation of proteins can be considered pivotal signaling in cardioprotection. Due to space constraint, we focus on S-nitrosylation. Useful information on the molecular mechanisms and potential clinical significance of S-glutathionylation can be found in the recent review by Dalle-Donne et al. (35).

\section{S-Nitrosylation}

Nitric oxide can be generated by enzymatic and nonenzymatic processes (213). Incorporation of $\mathrm{NO}^{\bullet}$ moieties by covalent bonding to protein groups is chemically possible in the case of cysteine thiols, tryptophan indols, and amines (lysine and N-terminal) $(172,204)$, although S-nitrosylation (i.e., the S-NO bond) can be considered the most important in the ischemia/reperfusion scenario, because of its higher reactivity, its occurrence in biological systems, and its influence on many protein functions. In fact, S-nitrosylation has emerged as an intriguing signaling modality, independently of the induction of cGMP production by $\mathrm{NO}^{*}$, effectively acting as a reversible molecular switch analogous to phosphorylation. From a terminology viewpoint, the incorporation of $\mathrm{NO}^{*} / \mathrm{NO}^{+}$moiety to a thiol can be clearly individuated because of the prefix "S-", referring to the incorporation of the moiety to a sulfur atom to form the S-NO bond. The term nitration, instead, describes the incorporation of nitrotriatomic group $\left(-\mathrm{NO}_{2}\right)$ at position 3 of the phenolic ring of tyrosine residues (Fig. 5). Although nitration may be a step of protective pathways (99), this modification is clearly related to the formation of peroxynitrite in cardiovascular diseases (for reviews, see Refs. $85,139,187)$.

Due to the complexity of $\mathrm{NO}^{\bullet}$ and thiol chemistry, there are many possible reaction mechanisms that can lead to Snitrosylation (Fig. 5), although which one prevails in vivo is still debated $(79,204)$. Of course, a complete view of the role of $\mathrm{NO}^{\circ}$ in cardioprotection must now include these cGMPindependent/redox-dependent along with "classical" cGMPdependent mechanisms. Indeed, the role of $\mathrm{NO}^{\circ}$ in the cardioprotection afforded by PreC $(21,92)$ and PostC (139, 142) has been well documented. Until recently, however, many studies have centered on elucidating the role of classical $\mathrm{NO}^{\circ}$ signaling through cGMP to the mitochondria (140). Recently Sun et al. (178-180) have shown that PreC may cause S-nitrosylation of proteins involved in $\mathrm{Ca}^{2+}$ handling and energetics. Intriguingly, many of the proteins showing increased S-nitrosylation with cardioprotection are mitochondrial proteins. It is likely that the high level of reactive cysteines in mitochondrial proteins, and the increased stability of $\mathrm{N}_{2} \mathrm{O}_{3}$ in the hydrophobic milieu of the mitochondria, would favor S-nitrosylation (21). Interestingly, although PostC and late-preconditioning both require $\mathrm{NO}^{\circ}$, protein S-nitrosylation has not been deeply examined under these conditions. We have shown that PostC induces an increase in S-nitrosylation of proteins, particularly low molecular weight proteins (150). In a recent study, addition of a mitochondriatargeted S-nitrosothiol at the beginning of reperfusion has also been found to be cardioprotective against ischemia/ reperfusion injury (154). Sun et al. (179) also showed that perfusion of hearts with GSNO improved left ventricular function and protected against ischemia. Among others, mitochondrial $\mathrm{F}_{1} \mathrm{~F}_{0} \mathrm{ATPase}-\alpha$-subunit and $\alpha$-ketoglutaratedehydrogenase were S-nitrosylated, and their activities were inhibited and enhanced, respectively. As said above, these results are in agreement with early studies, indicating that PreC saves post-ischemic ATP consumption, and protects against the loss of $\alpha$-ketoglutarate activity $(145,201)$.

The cardioprotection by estrogen observed under conditions of increased contractility has been shown to involve an increase of S-nitrosylation of proteins. In fact, estrogen results in upregulation of cardiac eNOS and $\mathrm{nNOS}$, and several S-nitrosylated proteins were identified, including the $\alpha$-ketoglutarate dehydrogenase, the $\mathrm{F}_{1} \mathrm{~F}_{0} \mathrm{ATPase}-\alpha$-subunit, the L-type calcium channel, and the cardiac sarcoplasmic reticulum $\mathrm{Ca}^{2+}$-ATPase, which reduces calcium loading during ischemia and early reperfusion, thereby reducing I/R injury (179). It has been suggested that atorvastatin- and sevoflurane-induced cardioprotection are mediated by increasing S-nitrosylation of cyclooxygenase-2 and sarcolemmal proteins, respectively $(5,18)$. Also the anti-apoptotic effect of $\mathrm{NO}^{\bullet}$ has been linked to the inhibition of caspase-3 activation through cGMP-dependent and -independent mechanisms. In particular, S-nitrosylation-denitrosylation of caspase-3 were mechanisms by which Fas ligand was controlling the process of apoptosis $(95,114)$.

S-nitrosylated proteins could elicit their regulatory effects and protect cells by changing the structure and activity of proteins (i.e., triggering signaling pathways), and/or protecting the modified cysteine residues from further irreversible modification under oxidative/nitrosative-stress, and/or 
allowing the activity of these proteins/enzymes to be restored more quickly during I/R (Fig. 6) (179). It should be noted that, though nitrosylation and denitrosylation do not require enzymatic activities, they may be influenced by the presence of enzymes, metals and, of course, $\mathrm{NO}^{\bullet}$ sources, thus determining compartmentalization $(13,114,117)$.

\section{S-sulfhydration}

Hydrogen sulfide is a gas that can be physiologically generated from L-cysteine by the action of two enzymes cystathionine beta-synthase (CBS) and cystathionine gammalyase (CSE). Hydrogen sulfide physiologically modifies cysteines in a large number of proteins by S-sulfhydration, converting $\mathrm{P}-\mathrm{SH}$ groups to persulfide group (P-SSH) (124), which thus appears to be another posttranslational modification for proteins (Fig. 5). Similar to nitrosylation the covalent modification in S-sulfhydration is reversed by reducing agents, such as DTT $(124,193)$. In the last few years, $\mathrm{H}_{2} \mathrm{~S}$ has been implicated in the regulation of several (patho)physiological processes such as vasodilatation, cardioinotropism, and cardioprotection, to name just few. For instance, in $\mathrm{CSE}^{-/-}$mice, vessels and the heart do not form $\mathrm{H}_{2} \mathrm{~S}$ and animals show endothelial-dysfunction and hypertension (111); CSE inhibitors augment post-ischemic cardiac damage and $\mathrm{H}_{2} \mathrm{~S}$ donors are able to trigger cell signaling, leading to cardioprotection $(47,111)$. Importantly, both endogenous and exogenous $\mathrm{H}_{2} \mathrm{~S}$ induce PostC-like cardioprotection, involving the Akt-eNOS-PKC pathway. Moreover, the PKC inhibitor chelerythrine and the $\mathrm{K}_{\mathrm{ATP}}$ channel blockers, glibenclamide or 5-hydroxydecanoate, are able to reverse the cardioprotective effects of the $\mathrm{H}_{2} \mathrm{~S}$-donor, NaHS $(89,203)$. While it is not clear whether and/or how $\mathrm{H}_{2} \mathrm{~S}$ modifies the activity of RISK/SAFE enzymes involved in PostC, it seems that $\mathrm{H}_{2} \mathrm{~S}$ directly alters the activity of $\mathrm{K}_{\mathrm{ATP}}$ channels. In fact, $\mathrm{NaSH}$ sulfhydrates the Kir6.1 subunit of $\mathrm{K}_{\mathrm{ATP}}$ channels exogenously expressed in HEK293 cells. Treatment with DTT reverses the NaHS-mediated $\mathrm{K}_{\mathrm{ATP}}$ sulfhydration (124). Moreover, $\mathrm{H}_{2} \mathrm{~S}$ interacts with $\mathrm{Cys} 6$ and $\mathrm{Cys} 26$ residues of the extracellular N-terminal of SUR1 subunit of $\mathrm{K}_{\text {ATP }}$ channel eterologhe complex. Direct chemical modification of SUR1 subunit protein may represent a molecular mechanism for the activation of $\mathrm{K}_{\text {ATP }}$ channels by $\mathrm{H}_{2} \mathrm{~S}$ (90). Yet at physiological concentrations, $\mathrm{H}_{2} \mathrm{~S}$ relaxes vascular tissues via the activation of sarcolemmal $\mathrm{K}_{\text {ATP }}$ channels in smooth muscle cells (193). Also the vasodilatation by garlic reflects $\mathrm{H}_{2} \mathrm{~S}$ action on $\mathrm{K}_{\text {ATP }}$ channels (111). Nevertheless, we should keep in mind that a direct $\mathrm{K}_{\mathrm{ATP}}$ sulfhydration has not been demonstrated in the cardioprotective context. Moreover, the molecular basis of $\mathrm{mK}_{\mathrm{ATP}}$ channels (in which cardioprotection seems more relevant than the sarcolemmal channels) remains unclear at present. Finally, it should be noted that cardiovascular $\mathrm{K}_{\mathrm{ATP}}$ channels are generally thought to consist of Kir6.2/SUR2A subunits, in the case of heart muscle, or Kir6.1/SUR2B subunits in smooth muscle sarcolemma. However, there have been several reports of Kir6.1 mRNA and protein expression in the hearts of human, guinea pig, chick, rat, and mouse (103).

In the long run, the inducible form of heme oxygenase (HO), HO-1, may play a key role in maintaining antioxidant and oxidant homeostasis when cellular injury occurs (110). Notably, the $\mathrm{H}_{2} \mathrm{~S}$ donor, diallyl sulfide, induces the activation of ERK, the expression and nuclear translocation of the tran- scription factor Nrf2, and the activation of ho- 1 gene. These results suggest that $\mathrm{H}_{2} \mathrm{~S}$ may play a role in prolonged protective effects by HO-1 overexpression (61). For additional data on the physiological role of $\mathrm{H}_{2} \mathrm{~S}$, see reviews $(111,182)$.

\section{Summary and Conclusions}

Myocardial damage during reperfusion, among other processes, can be due to oxidative stress, the cellular/mitochondrial $\mathrm{Ca}^{2+}$ overload, the reduced availability of $\mathrm{NO}^{*}$, the recovery of intracellular $\mathrm{pH}$, and the consequent formation of $\mathrm{mPTP}$, leading to the massive liberation of ROS/RNS. The $\mathrm{NO}^{\bullet}$ deficiency can also favor vasoconstriction, formation of micro-thrombi, adhesion of leucocytes to the endothelium, leading to the "no-reflow phenomenon" $(1,162,169)$.

Cardioprotection by ischemic pre- and postconditioning shares some of the signal transduction pathways. In particular, both PreC and PostC studies suggest that early reperfusion acidosis is necessary to avoid $\mathrm{mPTP}$ opening and to allow ROS signaling $(29,30,142)$. The protective cascades in early reperfusion converge on mitochondria and in particular on mPTP. In mitochondria, several proteins are phosphorylated. Beside kinase phosphorylation, other modalities of cell signaling are gaining ground. In particular, O-GlcNAcylation modification, S-nitrosylation, and S-sulfhydration of proteins are emerging as new signaling mechanisms that regulate cell function and play critical roles in mediating the response of cells to stress. It appears that when protein O-GlcNAcylation, S-nitrosylation, and S-sulfhydration increase, I/R injury is reduced, whereas when they decrease damage is exacerbated. However, we must keep in mind that the interplay between cell signaling may influence the outcomes. Cross-talk between different modalities of signaling may occur and may be the basis of controversial observations. Therefore a better understanding of this crosstalk may contribute to solve the conundrum relative to the role of RISK and/or SAFE pathway in cardioprotection deriving from conflicting results obtained with different models of pre- and postconditioning $(14,70$, $131,174,190)$. It will be important to understand how posttransitional modifications of different proteins are regulated in the context of cardioprotection. For instance, it is likely that S-nitrosylation of different protein controls does not solely vary in function of the amount of $\mathrm{NO}^{\circ}$. Data suggest that besides kinases, phosphatates, antioxidant enzymes, and NOSs, other enzymes such those involved in O-GlcNAcylation (OGA and OGT) and/or in $\mathrm{H}_{2} \mathrm{~S}$ synthesis (CBS and CSE) can modulate post-ischemic cardiomyocyte survival. Subcellular localization of enzymes may favor or contrast protein post-transitional modifications and this likely contributes to the differences in final outcome.

Mitochondria play a role of paramount importance in ROS/RNS signaling and in cardioprotection and many of the considered post-translational processes also occur in these organelles. Understanding the compartmentalized subcellular signaling and crosstalk among them is the challenge researchers should face in the future, to better fight ischemia/reperfusion injury, especially in the presence of other comorbidities and therapies.

\section{Acknowledgments}

The authors would like to thank Regione Piemonte, INRC, Bologna, MIUR (PRIN 2006, 2008) and Compagnia di San 
Paolo, Torino. The authors would also like to thank Prof. Donatella Gattullo for her invaluable support and Dr. Jennifer M. Lee for language revision.

\section{References}

1. Ambrosio G, Flaherty JT, Duilio C, Tritto I, Santoro G, Elia $\mathrm{PP}$, Condorelli $\mathrm{M}$, and Chiariello $\mathrm{M}$. Oxygen radicals generated at reflow induce peroxidation of membrane lipids in reperfused hearts. J Clin Invest 87: 2056-2066, 1991.

2. Ambrosio G, Zweier JL, Duilio C, Kuppusamy P, Santoro G, Elia PP, Tritto I, Cirillo P, Condorelli M, and Chiariello $\mathrm{M}$. Evidence that mitochondrial respiration is a source of potentially toxic oxygen free radicals in intact rabbit hearts subjected to ischemia and reflow. J Biol Chem 268: 1853218541, 1993.

3. Andersen HR, Nielsen TT, Vesterlund T, Grande P, Abildgaard U, Thayssen P, Pedersen F, Mortensen LS, and DANAMI-2 Investigators. Danish multicenter randomized study on fibrinolytic therapy versus acute coronary angioplasty in acute myocardial infarction: Rationale and design of the DANish trial in Acute Myocardial Infarction-2 (DANAMI-2). Am Heart J 146: 234-241, 2003.

4. Argaud L, Gateau-Roesch O, Raisky O, Loufouat J, Robert $\mathrm{D}$, and Ovize M. Postconditioning inhibits mitochondrial permeability transition. Circulation 111: 194-197, 2005.

5. Atar S, Ye Y, Lin Y, Freeberg SY, Nishi SP, Rosanio S, Huang M-H, Uretsky BF, Perez-Polo JR, and Birnbaum Y. Atorvastatin-induced cardioprotection is mediated by increasing inducible nitric oxide synthase and consequent S-nitrosylation of cyclooxygenase-2. Am J Physiol Heart Circ Physiol 290: H1960-H1968, 2006.

6. Baines CP, Kaiser RA, Purcell NH, Blair NS, Osinska H, Hambleton MA, Brunskill EW, Sayen MR, Gottlieb RA, Dorn GW, Robbins J, and Molkentin JD. Loss of cyclophilin D reveals a critical role for mitochondrial permeability transition in cell death. Nature 434: 658-662, 2005.

7. Baines $\mathrm{CP}$, Song CX, Zheng YT, Wang GW, Zhang J, Wang OL, Guo Y, Bolli R, Cardwell EM, and Ping P. Protein kinase Cepsilon interacts with and inhibits the permeability transition pore in cardiac mitochondria. Circ Res 92: 873880, 2003.

8. Baines $\mathrm{CP}$, Zhang J, Wang GW, Zheng YT, Xiu JX, Cardwell EM, Bolli R, and Ping P. Mitochondrial PKCepsilon and MAPK form signaling modules in the murine heart: Enhanced mitochondrial PKCepsilon-MAPK interactions and differential MAPK activation in PKCepsilon-induced cardioprotection. Circ Res 90: 390-397, 2002.

9. Baines CP. The mitochondrial permeability transition pore as a target of cardioprotective signaling. Am J Physiol Heart Circ Physiol 293: H903-H904, 2007.

10. Beauchamp P, Richard V, Tamion F, Lallemand F, Lebreton JP, Vaudry H, Daveau M, and Thuillez C. Protective effects of preconditioning in cultured rat endothelial cells: Effects on neutrophil adhesion and expression of ICAM-1 after anoxia and reoxygenation. Circulation 100: 541-546, 1999.

11. Beckman JS, Beckman TW, Chen J, Marshall PH, and Freeman BA. Apparent hydroxyl radical production by peroxylnitrites: Implications for endothelial injury from nitric oxide and superoxide. Proc Natl Acad Sci USA 87: 1620-1624, 1990.
12. Beckman JS and Koppenol WH. Nitric oxide, superoxide, and peroxynitrite: The good, the bad, and ugly. Am J Physiol Cell Physiol 271: C1424-1437, 1996.

13. Benhar M, Forrester MT, and Stamler JS. Protein denitrosylation: Enzymatic mechanisms and cellular functions. Nat Rev Mol Cell Biol 10: 721-732, 2009.

14. Boengler K, Heusch G, and Schulz R. Mitochondria in postconditioning. Antioxid Redox Signal 14: 863-880, 2011.

15. Boengler K, Hilfiker-Kleiner D, Drexler H, Heusch G, and Schulz R. The myocardial JAK/STAT pathway: From protection to failure. Pharmacol Ther 120: 172-185, 2008.

16. Boengler K, Stahlhofen S, van de Sand A, Gres P, RuizMeana M, Garcia-Dorado D, Heusch G, and Schulz R. Presence of connexin 43 in subsarcolemmal, but not in interfibrillar cardiomyocyte mitochondria. Basic Res Cardiol 104: 141-147, 2009.

17. Borutaite V, Jekabsone A, Morkuniene R, and Brown GC. Inhibition of mitochondrial permeability transition prevents mitochondrial dysfunction, cytochrome c release and apoptosis induced by heart ischemia. J Mol Cell Cardiol. 35: 339-341, 2003.

18. Bouwman RA, Musters RJP, van Beek-Harmsen Brechje J, de Lange Jaap J, and Boer C. Reactive oxygen species precede protein dinase C-[delta] activation independent of adenosine triphosphate-sensitive mitochondrial channel opening in sevoflurane-induced cardioprotection. Anesthesiology 100: 506-514, 2004.

19. Brookes PS, Salinas EP, Darley-Usmar K, Eiserich JP, Freeman BA, Darley-Usmar VM, and Anderson PG. Concentration-dependent effects of nitric oxide on mitochondrial permeability transition and cytochrome c release. $J$ Biol Chem 275:20474-20479, 2000.

20. Burnett G and Kennedy EP. The enzymatic phosphorylation of proteins. J Biol Chem 211: 969-980, 1954.

21. Burwell LS and Brookes PS. Mitochondria as a target for the cardioprotective effects of nitric oxide in ischemiareperfusion injury. Antioxid Redox Signal 10: 579-599, 2008.

22. Camara AK, Lesnefsky EJ, and Stowe DF. Potential therapeutic benefits of strategies directed to mitochondria. Antiox Redox Signal 13: 279-347, 2010.

23. Champattanachai V, Marchase RB, and Chatham JC. Glucosamine protects neonatal cardiomyocytes from ischemiareperfusion injury via increased protein O-GlcNAc and increased mitochondrial Bcl-2. Am J Physiol Cell Physiol 294: C1509-C1520, 2008.

24. Chen K, Craige SE, and Keaney JF Jr. Downstream targets and intracellular compartmentalization in Nox signaling. Antioxid Redox Signal 11: 2467-2480, 2009.

25. Chen L, Hahn H, Wu G, Chen C-H, Liron T, Schechtman D, Cavallaro G, Banci L, Guo Y, Bolli R, Dorn GW II, and Mochly-Rosen D Opposing cardioprotective actions and parallel hypertrophic effects of delta PKC and epsilon PKC. Proc Natl Acad Sci USA 98: 11114-11119, 2001.

26. Chen $\mathrm{Z}, \mathrm{Li} \mathrm{T}$, and Zhang B. Morphine postconditioning protects against reperfusion injury in the isolated rat hearts. J Surg Res 145: 287-294, 2008.

27. Chiara F, Castellaro D, Marin O, Petronilli V, Brusilow WS, Juhaszova M, Sollott SJ, Forte M, Bernardi P, and Rasola A. Hexokinase II detachment from mitochondria triggers apoptosis through the permeability transition pore independent of voltage-dependent anion channels. PLoS One 3:e1852, 2008. 
28. Churchill EN and Mochly-Rosen D. The roles of PKC $\delta$ and $\varepsilon$ isoenzymes in the regulation of myocardial ischaemia/ reperfusion injury. Biochem Soc Trans 35: 1040-1042, 2007.

29. Cohen MV and Downey JM Ischemic postconditioning: From receptor to end-effector. Antioxid Redox Signal 14: 821-831, 2011.

30. Cohen MV, Yang XM, and Downey JM. The $\mathrm{pH}$ hypothesis of postconditioning: staccato reperfusion reintroduces oxygen and perpetuates myocardial acidosis. Circulation 115: 1895-1903, 2007.

31. Crisafulli A, Melis F, Tocco F, Santoboni UM, Lai C, Angioy G, Lorrai L, Pittau G, Concu A, and Pagliaro P. Exerciseinduced and nitroglycerin-induced myocardial preconditioning improves hemodynamics in patients with angina. Am J Physiol Heart Circ Physiol 287: H235-242, 2004.

32. Crompton M. The mitochondrial permeability transition pore and its role in cell death. Biochem J 341: 233-249, 1999.

33. Daiber A. Redox signaling (cross-talk) from and to mitochondria involves mitochondrial pores and reactive oxygen species. Biochim Biophys Acta 1797: 897-906, 2010.

34. Daiber A, Schildknecht S, Müller J, Kamuf J, Bachschmid MM, and Ullrich V. Chemical model systems for cellular nitros(yl)ation reactions. Free Radic Biol Med 47: 458-467, 2009.

35. Dalle-Donne I, Milzani A, Gagliano N, Colombo R, Giustarini D, and Rossi R. Molecular mechanisms and potential clinical significance of S-glutathionylation. Antioxid Redox Signal 10: 445- 474, 2008.

36. Das M, Parker JE, and Halestrap AP. Matrix volume measurements challenge the existence of diazoxide/ glibencamide-sensitive KATP channels in rat mitochondria. J Physiol 547: 893-902, 2003.

37. Dennery PA. Regulation and role of heme oxygenase in oxidative injury. Curr Top Cell Regul 36: 181-199, 2000.

38. Di Lisa F and Bernardi P. Mitochondria and ischemiareperfusion injury of the heart: fixing a hole. Cardiovasc Res 70: 191-199, 2006.

39. Di Lisa F, Canton M, Carpi A, Kaludercic N, Menabò R, Menazza S, and Semenzato M. Mitochondrial injury and protection in ischemic pre- and post-conditioning. Antioxid Redox Signal 14: 881-891, 2011.

40. Di Lisa F, Canton M, Menabò R, Kaludercic N, and Bernardi P. Mitochondria and cardioprotection. Heart Fail Rev 12: 249-260, 2007.

41. Di Lisa F, Kaludercic N, Carpi A, Menabò R, and Giorgio M. Mitochondrial pathways for ROS formation and myocardial injury: The relevance of p66(Shc) and monoamine oxidase. Basic Res Cardiol 104: 131-139, 2009.

42. Downey JM and Cohen MV. O-linked beta-Nacetylglucosamine: A new piece of the cardioprotection puzzle? Circ Res 104: 7-8, 2009.

43. Downey JM and Cohen MV. A really radical observationa comment on Penna et al. in Basic Res Cardiol (2006) 101:180-189. Basic Res Cardiol. 101: 190-191, 2006.

44. Dragoni S, Gori T, Lisi M, Di Stolfo G, Pautz A, Kleinert H, and Parker JD. Pentaerythrityl tetranitrate and nitroglycerin, but not isosorbide mononitrate, prevent endothelial dysfunction induced by ischemia and reperfusion. Arterioscler Thromb Vasc Biol 27: 1955-1959, 2007.

45. Du XL, Edelstein D, Rossetti L, Fantus IG, Goldberg H, Ziyadeh F, Wu J, and Brownlee M. Hyperglycemia-induced mitochondrial superoxide overproduction activates the hexosamine pathway and induces plasminogen activator inhibitor-1 expression by increasing Sp1 glycosylation. Proc Natl Acad Sci USA 97: 12222-12226, 2000.

46. Eliseev RA, Malecki J, Lester T, Zhang Y, Humphrey J, and Gunter TE. Cyclophilin D interacts with Bcl2 and exerts an anti-apoptotic effect. J Biol Chem 284: 9692-9699, 2009.

47. Elrod J W, Calvert JW, Morrison J, Doeller JE, Kraus DW, Tao L, Jiao X, Scalia R, Kiss L, Szabó C, Kimura H, Chow $\mathrm{CW}$, and Lefer DJ. Hydrogen sulfide attenuates myocardial ischemia-reperfusion injury by preservation of mitochondrial function. Proc Natl Acad Sci USA 104: 15560-15565, 2007.

48. Fang JK, Prabu SK, Sepuri NB, Raza H, Anandatheerthavarada HK, Galati D, Spear J, and Avadhani NG. Site specific phosphorylation of cytochrome c oxidase subunits $\mathrm{I}$, IVi1 and $\mathrm{Vb}$ in rabbit hearts subjected to ischemia/reperfusion. FEBS Lett 581: 1302-1310, 2007.

49. Fantinelli JC and Mosca SM. Cardioprotective effects of a non-alcoholic extract of red wine during ischaemia and reperfusion in spontaneously hypertensive rats. Clin Exp Pharmacol Physiol 34: 166-169, 2007.

50. Feng J, Lucchinetti E, Ahuja P, Pasch T, Perriard JC, and Zaugg M. Isoflurane postconditioning prevents opening of the mitochondrial permeability transition pore through inhibition of glycogen synthase kinase 3beta. Anesthesiology 103: 987-995, 2005.

51. Feng J, Zhu M, Schaub MC, Gehrig P, Roschitzki B, Lucchinetti E, and Zaugg M. Phosphoproteome analysis of isoflurane-protected heart mitochondria: phosphorylation of adenine nucleotide translocator-1 on Tyr194 regulates mitochondrial function. Cardiovasc Res 80: 20-29, 2008.

52. Ferdinandy P and Schulz R. Nitric oxide, superoxide, and peroxynitrite in myocardial ischaemia-reperfusion injury and preconditioning. Br J Pharmacol 138: 532-543, 2003.

53. Ferdinandy P, Schulz R, and Baxter GF. Interaction of cardiovascular risk factors with myocardial ischemia/ reperfusion injury, preconditioning, and postconditioning. Pharmacol Rev 59: 418-458, 2007.

54. Fujita M, Asanuma H, Hirata A, Wakeno M, Takahama $\mathrm{H}$, Sasaki H, Kim J, Takashima S, Tsukamoto O, Minamino T, Shinozaki Y, Tomoike H, Hori M, and Kitakaze M. Prolonged transient acidosis during early reperfusion contributes to the cardioprotective effects of postconditioning. Am J Physiol Heart Circ Physiol 292: H2004-H2008, 2007.

55. Fukuto JM, Jackson MI, Kaludercic N, and Paolocci N. Examining nitroxyl in biological systems. Methods Enzymol 440: 411-431, 2008.

56. Galagudza M, Kurapeev D, Minasian S, Valen G, and Vaage J. Ischemic postconditioning: Brief ischemia during reperfusion converts persistent ventricular fibrillation into regular rhythm. Eur J Cardiothorac Surg 25: 1006-1010, 2004.

57. Garlid KD, Costa AD, Quinlan CL, Pierre SV, and Dos Santos P. Cardioprotective signaling to mitochondria. J Mol Cell Cardiol 46: 858-866, 2009.

58. Gateau-Roesch O, Argaud L, and Ovize M. Mitochondrial permeability transition pore and postconditioning. Cardiovasc Res 70: 264-273, 2006.

59. Gomez L, Li B, Mewton N, Sanchez I, Piot C, Elbaz M, and Ovize M. Inhibition of mitochondrial permeability transition pore opening: Translation to patients. Cardiovasc Res 83: 226-233, 2009.

60. Gomez L, Thibault HB, Gharib A, Dumont JM, Vuagniaux G, Scalfaro P, Derumeaux G, and Ovize M. Inhibition of mitochondrial permeability transition improves functional recovery and reduces mortality following acute myocardial 
infarction in mice. Am J Physiol Heart Circ Physiol 293: H1654-H1661, 2007.

61. Gong P, Hu B, and Cederbaum AI. Diallyl sulfide induces heme oxygenase-1 through MAPK pathway. Arch Biochem Biophys 432: 252-260, 2004.

62. Gottlieb RA, Finley KD, and Mentzer RM Jr. Cardioprotection requires taking out the trash. Basic Res Cardiol 104: 169-180, 2009.

63. Grech ED and Ramsdale DR. Termination of reperfusion arrhythmia by coronary artery occlusion. Br Heart $\mathrm{J}$ 72: 94-95, 1994.

64. Griffiths EJ and Halestrap AP. Mitochondrial nonspecific pores remain closed during cardiac ischaemia, but open upon reperfusion. Biochem J 307: 93-98, 1995.

65. Gross ER and Gross GJ. Ligand triggers of classical preconditioning and postconditioning. Cardiovasc Res 70: 212-221, 2006.

66. Halestrap AP. Calcium, mitochondria and reperfusion injury: A pore way to die. Biochem Soc Trans 34: 232-237, 2006.

67. Harada H, Becknell B, Wilm M, Mann M, Huang LJ, Taylor SS, Scott JD, and Korsmeyer SJ. Phosphorylation and inactivation of BAD by mitochondria-anchored protein kinase A. Mol Cell 3: 413-422, 1999.

68. Hausenloy DJ and Yellon DM. Preconditioning and postconditioning: New strategies for cardioprotection. Diabetes Obes Metab 10: 451-459, 2008.

69. Hausenloy DJ and Yellon DM. The mitochondrial permeability transition pore: Its fundamental role in mediating cell death during ischaemia and reperfusion. J Mol Cell Cardiol 35: 339-341, 2003.

70. Hausenloy DJ, Lecour S, and Yellon DM. Reperfusion Injury Salvage Kinase and Survivor Activating Factor Enhancement prosurvival signaling pathways in ischaemic postconditioning: Two sides of the same coin. Antioxid Redox Signal 14: 893-907, 2011.

71. Hausenloy DJ, Mocanu MM, and Yellon DM. Cross-talk between the survival kinases during early reperfusion: Its contribution to ischemic preconditioning. Cardiovasc Res 63: 305-312, 2004.

72. Hausenloy DJ, Ong SB, and Yellon DM. The mitochondrial permeability transition pore as a target for preconditioning and postconditioning. Basic Res Cardiol 104: 189-202, 2009.

73. Hausenloy DJ, Wynne AM, and Yellon DM. Ischemic preconditioning targets the reperfusion phase. Basic Res Cardiol 102: 445-452, 2007.

74. Helling S, Vogt S, Rhiel A, Ramzan R, Wen L, Marcus K, and Kadenbach B. Phosphorylation and kinetics of mammalian cytochrome c oxidase. Mol Cell Proteomics 7: 17141724, 2008.

75. Hess DT, Matsumoto A, Nudelman R, and Stamler JS. S-nitrosylation: Spectrum and specificity. Nat Cell Biol 3: E46-E49, 2001.

76. Heusch G. No risk, no...cardioprotection? A critical perspective. Cardiovasc Res 84: 173-175, 2009.

77. Heusch G. Postconditioning: Old wine in a new bottle? J Am Coll Cardiol 44: 1111-1112, 2004.

78. Horbinski $\mathrm{C}$ and $\mathrm{Chu} C \mathrm{CT}$. Kinase signaling cascades in the mitochondrion: A matter of life or death. Free Radic Biol Med 38: 2-11, 2005.

79. Hurd TR, Costa NJ, Dahm CC, Beer SM, Brown SE, Filipovska A, and Murphy MP. Glutathionylation of mitochondrial proteins. Antioxid Redox Signal 7: 999-1010, 2005.

80. Hurd TR, Prime TA, Harbour ME, Lilley KS, and Murphy MP. Detection of reactive oxygen species-sensitive thiol proteins by redox difference gel electrophoresis: Implications for mitochondrial redox signaling. J Biol Chem 282: 22040-22051, 2007.

81. Iliodromitis EK, Andreadou I, Prokovas E, Zoga A, Farmakis D, Fotopoulou T, Ioannidis K, Paraskevaidis IA, and Kremastinos DT. Simvastatin in contrast to postconditioning reduces infarct size in hyperlipidemic rabbits: Possible role of oxidative/nitrosative stress attenuation. Basic Res Cardiol 105: 193-203, 2010.

82. Iliodromitis EK, Downey JM, Heusch G, and Kremastinos DT. What is the optimal postconditioning algorithm? J Cardiovasc Pharmacol Ther 14: 269-273, 2009.

83. Inserte J, Barba I, Hernando V, Abellán A, Ruiz-Meana M, Rodríguez-Sinovas A, and Garcia-Dorado D. Effect of acidic reperfusion on prolongation of intracellular acidosis and myocardial salvage. Cardiovasc Res 77: 782-790, 2008.

84. Inserte J, Ruiz-Meana M, Rodríguez-Sinovas A, Barba I, and Garcia-Dorado D. Contribution of delayed intracellular $\mathrm{pH}$ recovery to ischemic postconditioning protection. Antioxid Redox Signal 14: 923-939, 2011.

85. Ischiropoulos H. Biological selectivity and functional aspects of protein tyrosine nitration. Biochem Biophys Res Commun 305: 776-783, 2003.

86. Ivanès F, Rioufol G, Piot $C$, and Ovize $M$. Postconditioning in acute myocardial infarction patients. Antioxid Redox Signal 14: 811-820, 2011.

87. Janssen-Heininger YM, Mossman BT, Heintz NH, Forman HJ, Kalyanaraman B, Finkel T, Stamler JS, Rhee SG, and van der Vliet A. Redox-based regulation of signal transduction: Principles, pitfalls, and promises. Free Radic Biol Med 45: 1-17, 2008.

88. Jensen $\mathrm{ON}$. Interpreting the protein language using proteomics. Nat Rev Mol Cell Biol 7: 391-403, 2006.

89. Ji Y, Pang QF, Xu G, Wang L, Wang JK, and Zeng YM. Exogenous hydrogen sulfide postconditioning protects isolated rat hearts against ischemia-reperfusion injury. Eur J Pharmacol 587: 1-7, 2008.

90. Jiang B, Tang G, Cao K, Wu L, and Wang R. Molecular mechanism for $\mathrm{H}_{2} \mathrm{~S}$-induced activation of KATP channels. Antioxid Redox Signal 12: 1167-1178, 2010.

91. Jin ZQ, Karliner JS, and Vessey DA. Ischaemic postconditioning protects isolated mouse hearts against ischaemia/reperfusion injury via sphingosine kinase isoform-1 activation. Cardiovasc Res 79: 134-140, 2008.

92. Jones SP and Bolli R. The ubiquitous role of nitric oxide in cardioprotection. J Mol Cell Cardiol 40: 16-23, 2006.

93. Jones SP, Zachara NE, Ngoh GA, Hill BG, Teshima Y, Bhatnagar A, Hart GW, and Marban E. Cardioprotection by $\mathrm{N}$-acetylglucosamine linkage to cellular proteins. Circulation 117: 1172--1182, 2008.

94. Kane LA and Van Eyk JE. Post-translational modifications of ATP synthase in the heart: Biology and function. J Bioenerg Biomembr 41: 145-150, 2009.

95. Kim YM, Talanian RV, and Billiar TR. Nitric oxide inhibits apoptosis by preventing increases in caspase-3-like activity via two distinct mechanisms. J Biol Chem 272: 31138-31148, 1997.

96. Kloner RA, Dow J, and Bhandari A. Postconditioning markedly attenuates ventricular arrhythmias after ischemiareperfusion. J Cardiovasc Pharmacol Ther 11: 55-63, 2006.

97. Kokoszka JE, Waymire KG, Levy SE, Sligh JE, Cai J, Jones DP, MacGregor GR, and Wallace DC. The ADP/ATP translocator is not essential for the mitochondrial permeability transition pore. Nature 427: 461-465, 2004. 
98. Korichneva I. Zinc dynamics in the myocardial redox signaling network. Antioxid Redox Signal 8: 1707-1721, 2006.

99. Kupai K, Csonka C, Fekete V, Odendaal L, van Rooyen J, Marais de W, Csont T, and Ferdinandy P. Cholesterol dietinduced hyperlipidemia impairs the cardioprotective effect of postconditioning: Role of peroxynitrite. Am J Physiol Heart Circ Physiol 297: H1729-H1735, 2009.

100. Kusuoka H and Marban E. Cellular mechanisms of myocardial stunning. Annu Rev Physiol 54: 243-256, 1992.

101. Laczy B, Bradford GH, Wang K, Paterson AJ, White CR, Xing D, Chen Y-F, Darley-Usmar V, Oparil S, and Chatham JC. Proteine O-GlcNAcylation: A new signaling paradigm for the cardiovascular system. Am J Physiol Heart Circ Physiol 296: H13- H28, 2009.

102. Lecour S. Activation of the protective Survivor Activating Factor Enhancement (SAFE) pathway against reperfusion injury: Does it go beyond the RISK pathway? J Mol Cell Cardiol 47: 32-40, 2009.

103. Lefer DJ, Nichols CG, and Coetzee WA. Sulfonylurea receptor 1 subunits of ATP-sensitive potassium channels and myocardial ischemia/reperfusion injury. Trends Cardiovasc Med 19: 61-67, 2009.

104. Lewandrowski U, Sickmann A, Cesaro L, Brunati AM, Toninello A, and Salvi M. Identification of new tyrosine phosphorylated proteins in rat brain mitochondria. FEBS Lett 582: 1104-1110, 2008.

105. Lim SY, Davidson SM, Hausenloy DJ, and Yellon DM. Preconditioning and postconditioning: The essential role of the mitochondrial permeability transition pore. Cardiovasc Res 75: 530-535, 2007.

106. Liu J, Marchase RB, and Chatham JC. Glutamine-induced protection of isolated rat heart from ischemia/reperfusion injury is mediated via the hexosamine biosynthesis pathway and increased protein O-GlcNAc levels. J Mol Cell Cardiol 42: 177-185, 2007.

107. Liu J, Marchase RB, and Chatham JC. Increased O-GlcNAc levels during reperfusion lead to improved functional recovery and reduced calpain proteolysis. Am J Physiol Heart Circ Physiol 293: H1391-H1399, 2007.

108. Lizasoain I, Moro MA, Knowles RG, Darley-Usmar V, and Moncada S. Nitric oxide and peroxynitrite exert distinct effects on mitochondrial respiration which are differentially blocked by glutathione or glucose. Biochem J 314: 877-880, 1996.

109. Ludman AJ, Yellon DM, and Hausenloy DJ. Cardiac preconditioning for ischaemia: lost in translation. Dis Model Mech 3: 35-38, 2010.

110. Maines MD. The heme oxygenase system: A regulator of second messenger gases. Annu Rev Pharmacol Toxicol 37: 517-554, 1997.

111. Mancardi D, Penna C, Merlino A, Del Soldato P, Wink DA, and Pagliaro P. Physiological and pharmacological features of the novel gasotransmitter: Hydrogen sulfide. Biochim Biophys Acta 1787: 864-872, 2009.

112. Mancardi D, Ridnour LA, Thomas DD, Katori T, Tocchetti CG, Espey MG, Miranda KM, Paolocci N, and Wink DA. The chemical dynamics of $\mathrm{NO}$ and reactive nitrogen oxides: A practical guide. Curr Mol Med 4: 723-740, 2004.

113. Manintveld OC, Hekkert ML, van der Ploeg NT, Verdouw PD, and Duncker DJ. Interaction between pre- and postconditioning in the in vivo rat heart. Exp Biol Med (Maywood) 234: 1345-1354, 2009.

114. Mannick JB, Hausladen A, Liu L, Hess DT, Zeng M, Miao QX, Kane LS, Gow AJ, and Stamler JS. Fas-induced caspase denitrosylation. Science 284: 651-654, 1999.
115. Mannick JB, Schonhoff C, Papeta N, Ghafourifar P, Szibor M, Fang K, and Gaston B. S-Nitrosylation of mitochondrial caspases. J Cell Biol 154: 1111-1116, 2001.

116. Marczin N, El-Habashi N, Hoare GS, Bundy RE, and Yacoub M. Antioxidants in myocardial ischemia-reperfusion injury: Therapeutic potential and basic mechanisms. Arch Biochem Biophys 420: 222-236, 2003.

117. Mitchell DA and Marletta MA. Thioredoxin catalyzes the S-nitrosation of the caspase-3 active site cysteine. Nat Chem Biol 1: 154-158, 2005.

118. Mochly-Rosen D and Gordon AS. Anchoring proteins for protein kinase C: A means for isozyme selectivity. FASEB J 12: 35-42, 1998.

119. Moncada S and Erusalimsky JD. Does nitric oxide modulate mitochondrial energy generation and apoptosis? Nat Rev Mol Cell Biol 3: 214-220, 2002.

120. Morrison DA, Berman M, El-Amin O, McLaughlin RT, and Bates ER. Emergency percutaneous coronary intervention (PCI) for the care of patients with ST-elevation myocardial infarction (STEMI). Minerva Cardioangiol 55: 593-623, 2007.

121. Murphy E and Steenbergen C. Mechanisms underlying acute protection from cardiac ischemia-reperfusion injury. Physiol Rev 88: 581-609, 2008.

122. Murphy E and Steenbergen C. Preconditioning: The mitochondrial connection. Annu Rev Physiol 69: 51-67, 2007.

123. Murry CE, Jennings RB, and Reimer KA. Preconditioning with ischemia: A delay of lethal cell injury in ischemic myocardium. Circulation 74: 1124-1136, 1986.

124. Mustafa AK, Gadalla MM, Sen N, Kim S, Mu W, Gazi SK, Barrow RK, Yang G, Wang R, and Snyder SH. $\mathrm{H}_{2} \mathrm{~S}$ signals through protein S-sulfhydration. Sci Signal 2:ra72, 2009.

125. Na HS, Kim YI, Yoon YW, Han HC, Nahm SH, and Hong SK. Ventricular premature beat-driven intermittent restoration of coronary blood flow reduces the incidence of reperfusion-induced ventricular fibrillation in a cat model of regional ischemia. Am Heart J 132: 78-83, 1996.

126. Nakagawa T, Shimizu S, Watanabe T, Yamaguchi O, Otsu $\mathrm{K}$, Yamagata $\mathrm{H}$, Inohara $\mathrm{H}, \mathrm{Kubo} \mathrm{T}$, and Tsujimoto $\mathrm{Y}$. Cyclophilin D-dependent mitochondrial permeability transition regulates some necrotic but not apoptotic cell death. Nature 434: 652-658, 2005.

127. Nakayama $H$, Chen $X$, Baines $C P$, Klevitsky R, Zhang $X$, Zhang H, Jaleel N, Chua BH, Hewett TE, Robbins J, Houser SR, and Molkentin JD. $\mathrm{Ca}^{2+}$ and mitochondrial-dependent cardiomyocyte necrosis as a primary mediator of heart failure. J Clin Invest 117: 2431-2444, 2007.

128. Ngoh GA and Jones SP. New insights into metabolic signaling and cell survival: The role of beta-O-linkage of $\mathrm{N}$ acetylglucosamine. J Pharmacol Exp Ther 327: 602-609, 2008.

129. Ngoh GA, Facundo HT, Hamid T, Dillmann W, Zachara NE, and Jones SP. Unique hexosaminidase reduces metabolic survival signal and sensitizes cardiac myocytes to hypoxia/reoxygenation injury. Circ Res 104: 41-49, 2009.

130. Ngoh GA, Watson LJ, Facundo HT, Dillmann W, and Jones SP. Non-canonical glycosyltransferase modulates posthypoxic cardiac myocyte death and mitochondrial permeability transition. J Mol Cell Cardiol 45: 313-325, 2008.

131. Nishino Y, Webb IG, Davidson SM, Ahmed AI, Clark JE, Jacquet S, Shah AM, Miura T, Yellon DM, Avkiran M, and Marber MS. Glycogen synthase kinase-3 inactivation is not required for ischemic preconditioning or postconditioning in the mouse. Circ Res 103: 307-314, 2008.

132. Ogbi $\mathrm{M}$ and Johnson JA. Protein kinase $\mathrm{C}$ epsilon interacts with cytochrome $\mathrm{c}$ oxidase subunit IV and enhances 
cytochrome c oxidase activity in neonatal cardiac myocyte preconditioning. Biochem J 393: 191-199, 2006.

133. Onody A, Csonka C, Giricz Z, and Ferdinandy P. Hyperlipidemia induced by a cholesterol-rich diet leads to enhanced peroxynitrite formation in rat hearts. Cardiovasc Res 58: 663-670, 2003.

134. Otani H. Ischemic preconditioning: From molecular mechanisms to therapeutic opportunities. Antioxid Redox Signal 10: 207-247, 2008.

135. Pacher P, Beckman JS, and Liaudet L. Nitric oxide and peroxynitrite in health and disease. Physiol Rev 87: 315-424, 2007.

136. Pagliarini DJ and Dixon JE. Mitochondrial modulation: Reversible phosphorylation takes center stage? Trends Biochem Sci 31: 26-34, 2006.

137. Pagliaro P. Differential biological effects of products of nitric oxide (NO) synthase: It is not enough to say NO. Life Sci 73: 2137-2149, 2003.

138. Paolocci N, Jackson MI, Lopez BE, Miranda K, Tocchetti CG, Wink DA, Hobbs AJ, and Fukuto JM. The pharmacology of nitroxyl $\left(\mathrm{HNO} / \mathrm{NO}^{-}\right)$and its therapeutic potential: Not just the Janus face of NO. Pharmacol Ther 113: 442-458, 2007.

139. Penna C, Cappello S, Mancardi D, Raimondo S, Rastaldo R, Gattullo D, Losano G, and Pagliaro P. Post-conditioning reduces infarct size in the isolated rat heart: Role of coronary flow and pressure and the nitric oxide/cGMP pathway. Basic Res Cardiol 101: 168-179, 2006.

140. Penna C, Mancardi D, Raimondo S, Geuna S, and Pagliaro $\mathrm{P}$. The paradigm of postconditioning to protect the heart. $J$ Cell Mol Med 12: 435-458, 2008.

141. Penna C, Mancardi D, Rastaldo R, Losano G, and Pagliaro $P$. Intermittent activation of bradykinin $B_{2}$ receptors and mitochondrial $\mathrm{K}_{\text {ATP }}$ channels trigger cardiac postconditioning through redox signaling. Cardiovasc Res 75: 168-177, 2007.

142. Penna C, Mancardi D, Rastaldo R, and Pagliaro P. Cardioprotection: A radical view free radicals in pre and postconditioning. Biochim Biophys Acta 1787: 781-793, 2009.

143. Penna C, Mancardi D, Tullio F, and Pagliaro P. Intermittent adenosine at the beginning of reperfusion does not trigger cardioprotection, J Surg Res 153: 231-238, 2009.

144. Penna C, Mancardi D, Tullio F, and Pagliaro P. Postconditioning and intermittent bradykinin induced cardioprotection require cyclooxygenase activation and prostacyclin release during reperfusion. Basic Res Cardiol 103: 368-377, 2008.

145. Penna C, Pagliaro P, Rastaldo R, Di Pancrazio F, Lippe G, Gattullo D, Mancardi D, Samaja M, Losano G, and Mavelli I. F0F1 ATP synthase activity is differently modulated by coronary reactive hyperemia before and after ischemic preconditioning in the goat. Am J Physiol Heart Circ Physiol 287: H2192-H1200, 2004.

146. Penna C, Perrelli MG, Raimondo S, Tullio F, Merlino A, Moro F, Geuna S, Mancardi D, and Pagliaro P. Postconditioning induces an anti-apoptotic effect and preserves mitochondrial integrity in isolated rat hearts. Biochim Biophys Acta 1787: 794-801, 2009.

147. Penna C, Rastaldo R, Mancardi D, Raimondo S, Cappello S, Gattullo D, Losano G, and Pagliaro P. Post-conditioning induced cardioprotection requires signaling through a redox-sensitive mechanism, mitochondrial ATP-sensitive $\mathrm{K}^{+}$ channel and protein kinase C activation. Basic Res Cardiol 101: 180-189, 2006.
148. Penna C, Tullio F, Merlino A, Moro F, Raimondo S, Rastaldo R, Perrelli MG, Mancardi D, and Pagliaro P. Postconditioning cardioprotection against infarct size and post-ischemic systolic dysfunction is influenced by gender. Basic Res Cardiol 104: 390-402, 2009.

149. Penna C, Tullio F, Moro F, Folino A, Merlino A, and Pagliaro P. Effects of a protocol of ischemic postconditioning and/or captopril in hearts of normotensive and hypertensive rats. Basic Res Cardiol 105: 181-192, 2010.

150. Penna C, Tullio F, Perrelli M, Moro F, Parisella ML, Merlino $\mathrm{A}$, and Pagliaro P. Involvement of catalase (CAT), superoxide dismutase (SOD), reactive species (RNS), and protein nitrosylation in postconditioning (PostC) cardioprotection. Acta Physiol 197: p93 (Abstract), 2009.

151. Piper HM, Meuter K, and Schafer C. Cellular mechanisms of ischemia-reperfusion injury. Ann Thorac Surg 75: S644S648, 2003.

152. Poole LB, Karplus PA, and Claiborne A. Protein sulfenic acids in redox signaling. Annu Rev Pharmacol Toxicol 44: 325-347, 2004.

153. Prabu SK, Anandatheerthavarada HK, Raza H, Srinivasan S, Spear JF, and Avadhani NG. Protein kinase A-mediated phosphorylation modulates cytochrome c oxidase function and augments hypoxia and myocardial ischemia-related injury. J Biol Chem 281: 2061-2070, 2006.

154. Prime TA, Blaikie FH, Evans C, Nadtochiy SM, James AM, Dahm CC, Vitturi DA, Patel RP, Hiley CR, Abakumova I, Requejo R, Chouchani ET, Hurd TR, Garvey JF, Taylor CT, Brookes PS, Smith RAJ, and Murphy MP. A mitochondriatargeted S-nitrosothiol modulates respiration, nitrosates thiols, and protects against ischemia-reperfusion injury. Proc Natl Acad Sci U S A 106:10764-10769, 2009.

155. Przyklenk K, Maynard M, Greiner DL, and Whittaker P. Cardioprotection with postconditioning: loss of efficacy in murine models of type- 2 and type- 1 diabetes. Antioxid Redox Signal 14: 781-790, 2011.

156. Przyklenk K. Lethal myocardial reperfusion injury: The opinions of good men. J Thrombosis Thrombolysis 4: 37-39, 1997.

157. Raat NJ, Shiva S, and Gladwin MT. Effects of nitrite on modulating ROS generation following ischemia and reperfusion Adv Drug Deliv Rev. 61: 339-350, 2009.

158. Radi R, Cassina A, Hodara R, Quijano C and Castro L. Peroxynitrite reactions and formation in mitochondria. Free Radic Biol and Med 33: 1451-1464, 2002.

159. Radi R, Beckman JS, Bush KM, and Freeman BA. Peroxynitrite oxidation of sulfhydryls. The cytotoxic potential of superoxide and nitric oxide. J Biol Chem 266: 4244-4250, 1991.

160. Rajamani U and Essop MF. Hyperglycemia-mediated activation of the hexosamine biosynthetic pathway results in myocardial apoptosis. Am J Physiol Cell Physiol 299: C139C147, 2010.

161. Rathore R, Zheng YM, Niu CF, Liu QH, Korde A, Ho YS, and Wang YX. Hypoxia activates NADPH oxidase to increase [ROS]i and [Ca2+]i through the mitochondrial ROS-PKCepsilon signaling axis in pulmonary artery smooth muscle cells. Free Radic Biol Med 45: 1223-1231, 2008.

162. Reffelmann $\mathrm{T}$ and Kloner RA. The "no-reflow" phenomenon: Basic science and clinical correlates. Heart 87: 162-168, 2002.

163. Reimer KA, Murry CE, and Richard VJ. The role of neutrophils and free radicals in the ischemic-reperfused heart: 
Why the confusion and controversy? J Mol Cell Cardiol 21: 1225-1239, 1989.

164. Ridnour LA, Thomas DD, Mancardi D, Donzelli S, Paolocci N, Pagliaro P, Miranda KM, MC Krishna, Fukuto J, Grisham MB, Mitchell JB, Espey MG, and Wink DA. Antioxidant properties of nitric oxide in cellular physiological and pathophysiological mechanisms. The implications of biological balance between $\mathrm{NO}$ and oxidative stress. Curr Med Chem-Anti-Inflamm Anti-Allergy Agents 3: 181-188, 2004.

165. Ronson RS, Nakamura M, and Vinten-Johansen J. The cardiovascular effects and implications of peroxynitrite. Cardiovasc Res 44: 47-59, 1999.

166. Sabri A, Byron KL, Samarel AM, Bell J, and Lucchesi PA. Hydrogen peroxide activates mitogen-activated protein kinases and $\mathrm{Na}+-\mathrm{H}+$ exchange in neonatal rat cardiac myocytes. Circ Res 82: 1053-1062, 1998.

167. Saini HK, Machackova J and Dhalla NS. Role of reactive oxygen species in ischemic preconditioning of subcellular organelles in the heart. Antioxid Redox Signal 6: 393-404, 2004.

168. Sasaki N, Sato T, Ohler A, O'Rourke B, and Marban E. Activation of mitochondrial ATP-dependent potassium channels by nitric oxide. Circulation 101: 439-445, 2000.

169. Schulz R, Kelm M, and Heusch G. Nitric oxide in myocardial ischemia/reperfusion injury. Cardiovasc Res 61: 402-413, 2004

170. Siegmund B, Schluter KD, and Piper HM. Calcium and the oxygen paradox. Cardiovasc Res 27: 1778-1783, 1993.

171. Simon DI, Mullins ME, Jia L, Gaston B, Singel DJ, and Stamler JS. Polynitrosylated proteins: Characterization, bioactivity, and functional consequences. Proc Natl Acad Sci U S A 93: 4736-4741, 1996.

172. Sivaraman V, Mudalagiri NR, Di Salvo C, Kolvekar S, Hayward M, Yap J, Keogh B, Hausenloy DJ, and Yellon DM. Postconditioning protects human atrial muscle through the activation of the RISK pathway. Basic Res Cardiol 102: 453-459, 2007.

173. Skyschally A, van Caster P, Boengler K, Gres P, Musiolik J, Schilawa D, Schulz R, and Heusch G. Ischemic postconditioning in pigs no causal role for risk activation. Circ Res 104: 15-18, 2009.

174. Skyschally A, van Caster P, Iliodromitis EK, Schulz R, Kremastinos DT, and Heusch G. Ischemic postconditioning: Experimental models and protocol algorithms. Basic Res Cardiol 104: 469-483, 2009.

175. Smith FD, Langeberg LK, and Scott JD. The where's and when's of kinase anchoring. Trends Biochem Sci 31: 316-323, 2006.

176. Staat P, Rioufol G, Piot C, Cottin Y, Cung TT, L'Huillier I, Aupetit JF, Bonnefoy E, Finet G, André-Fouët X, and Ovize M. Postconditioning the human heart. Circulation 112: 2143-2148, 2005.

177. Stein AB, Tang XL, Guo Y, Xuan YT, Dawn B, and Bolli R. Delayed adaptation of the heart to stress: Late preconditioning. Stroke 35: 2676-2679, 2004.

178. Sun J, Morgan M, Shen RF, Steenbergen C, and Murphy E. Preconditioning results in S-nitrosylation of proteins involved in regulation of mitochondrial energetics and calcium transport. Circ Res 101: 1155-1163, 2007.

179. Sun J, Picht E, Ginsburg KS, Bers DM, Steenbergen C, and Murphy E. Hypercontractile female hearts exhibit increased S-nitrosylation of the L-type $\mathrm{Ca}^{2+}$ channel $\alpha 1$ subunit and reduced ischemia/reperfusion injury. Circ Res 98: 403-411, 2006.

180. Sun J, Steenbergen C, and Murphy E. S-nitrosylation: NOrelated redox signaling to protect against oxidative stress. Antioxid Redox Signal 8: 1693-1705, 2006.

181. Takagi H, Matsui $Y$, and Sadoshima J. The role of autophagy in mediating cell survival and death during ischemia and reperfusion in the heart. Antioxid Redox Signal 9: 13731381, 2007.

182. Tota B, Angelone T, Mancardi D and Cerra MC. Hypoxia and anoxia tolerance of vertebrate hearts: An evolutionary perspective. Antioxid Redox Signal 14: 851-862, 2011.

183. Tritto I and Ambrosio G. Role of oxidants in the signaling pathway of preconditioning. Antioxid Redox Signal 3: 3-10, 2001.

184. Tritto I, D'Andrea D, Eramo N, Scognamiglio A, De Simone C, Violante A, Esposito A, Chiariello M, and Ambrosio G. Oxygen radicals can induce preconditioning in rabbit hearts. Circ Res 80: 743-748, 1997.

185. Tsang A, Hausenloy DJ, Mocanu MM, and Yellon DM. Postconditioning: A form of "modified reperfusion" protects the myocardium by activating the phosphatidylinositol 3-kinase-Akt pathway. Circ Res 95: 230-232, 2004.

186. Tsutsumi YM, Yokoyama T, Horikawa Y, Roth DM, and Patel $\mathrm{HH}$. Reactive oxygen species trigger ischemic and pharmacological postconditioning: In vivo and in vitro characterization. Life Sci 81: 1223-1227, 2007.

187. Turko IV and Murad F. Protein nitration in cardiovascular diseases. Pharmacol Rev 54: 619-634, 2002.

188. Ullrich V and Kissner R. Redox signaling: bioinorganic chemistry at its best. J Inorg Biochem 100: 2079-2086, 2006.

189. van der Worp HB, Howells DW, Sena ES, Porritt MJ, Rewell S, O'Collins V, and Macleod MR. Can animal models of disease reliably inform human studies? PLoS Med 7: e1000245, 2010.

190. Vinten-Johansen J, Granfeldt A, Mykytenko J, Undyala VV, Dong Y, and Przyklenk K. The multidimensional physiological responses to postconditioning. Antioxid Redox Signal 14: 791-810, 2011.

191. Vinten-Johansen J, Zhao ZQ, Zatta AJ, Kin H, Halkos ME, and Kerendi F. Postconditioning-A new link in nature's armor against myocardial ischemia-reperfusion injury. $B a-$ sic Res Cardiol 100: 295-310, 2005.

192. Wang HC, Zhang HF, Guo WY, Su H, Zhang KR, Li QX, Yan W, Ma XL, Lopez BL, Christopher TA, and Gao F. Hypoxic postconditioning enhances the survival and inhibits apoptosis of cardiomyocytes following reoxygenation: Role of peroxynitrite formation. Apoptosis 11: 1453-1460, 2006.

193. Wang R. The gasotransmitter role of hydrogen sulfide. Antioxid Redox Signal 5: 493-501, 2003.

194. Wang Z, Gucek M, and Hart GW. Cross-talk between GlcNAcylation and phosphorylation: Site-specific phosphorylation dynamics in response to globally elevated $\mathrm{O}$ GlcNAc. Proc Natl Acad Sci USA 105: 13793-13798, 2008.

195. Wang Z, Pandey A, and Hart GW. Dynamic interplay between O-linked $\mathrm{N}$-acetylglucosaminylation and glycogen synthase kinase-3-dependent phosphorylation. Mol Cell Proteomics 6: 1365-1379, 2007.

196. Weiss JN, Korge P, Honda HM, and Ping P. Role of the mitochondrial permeability transition in myocardial disease. Circ Res 93: 292-301, 2003. 
197. Wells L, Vosseller K, and Hart GW. Glycosylation of nucleocytoplasmic proteins: Signal transduction and OGlcNAc. Science 291: 2376-2378, 2001.

198. Wink DA, Miranda KM, Katori T, Mancardi D, Thomas DD, Ridnour L, Espey MG, Feelisch M, Colton CA, Fukuto JM, Pagliaro P, Kass DA, and Paolocci N. Orthogonal properties of the redox siblings nitroxyl and nitric oxide in the cardiovascular system: A novel redox paradigm. Am J Physiol Heart Circ Physiol 285: H2264-H2276, 2003.

199. Wong W and Scott JD. AKAP signalling complexes: Focal points in space and time. Nat Rev Mol Cell Biol 5: 959-970, 2004.

200. Xi L, Das A, Zhao ZQ, Merino VF, Bader M, and Kukreja $\mathrm{RC}$. Loss of myocardial ischemic postconditioning in adenosine $\mathrm{A} 1$ and bradykinin $\mathrm{B} 2$ receptors gene knockout mice. Circulation 118: S32-S37, 2008.

201. Yellon DM and Downey JM. Preconditioning the myocardium: From cellular physiology to clinical cardiology. Physiol Rev 83: 1113-1151, 2003.

202. Yellon DM and Hausenloy DJ. Myocardial reperfusion injury. N Engl J Med 357: 1121-1135, 2007.

203. Yong QC, Lee SW, Foo CS, Neo KL, Chen X, and Bian JS. Endogenous hydrogen sulphide mediates the cardioprotection induced by ischemic postconditioning. Am J Physiol Heart Circ Physiol 295: H1330-H1340, 2008.

204. Zhang YY, Xu AM, Nomen M, Walsh M, Keaney JF Jr, and Loscalzo J. Nitrosation of tryptophan residue(s) in serum albumin and model dipeptides. Biochemical characterization and bioactivity. J Biol Chem 271: 14271-14279, 1996.

205. Zhao ZQ and Vinten-Johansen J. Myocardial apoptosis and ischemic preconditioning. Cardiovasc Res 55; 438-455, 2002.

206. Zhao ZQ and Vinten-Johansen J. Postconditioning: Reduction of reperfusion-induced injury. Cardiovasc Res 70: 200-211, 2006.

207. Zhao ZQ, Corvera JS, Halkos ME, Kerendi F, Wang NP, Guyton RA, and Vinten-Johansen J. Inhibition of myocardial injury by ischemic postconditioning during reperfusion: Comparison with ischemic preconditioning. Am J Physiol Heart Circ Physiol 285: H579-H588, 2003. Erratum in: Am J Physiol Heart Circ Physiol 286; H477, 2004.

208. Zhao ZQ. Oxidative stress-elicited myocardial apoptosis during reperfusion. Curr Opin Pharmacol 4: 159-165, 2004.

209. Zorov DB, Filburn CR, Klotz LO, Zweier JL, and Sollott SJ. Reactive oxygen species (ROS)-induced ROS release: A new phenomenon accompanying induction of the mitochondrial permeability transition in cardiac myocytes. J Exp Med 192: 1001-1014, 2000.

210. Zorov DB, Juhaszova M, and Sollott SJ. Mitochondrial ROS-induced ROS release: An update and review. Biochim Biophys Acta 1757: 509-517, 2006.

211. Zou M, Martin C, and Ullrich V. Tyrosine nitration as a mechanism of selective inactivation of prostacyclin synthase by peroxynitrite. Biol Chem 378: 707-713, 1997.

212. Zou MH, Shi C, and Cohen RA. Oxidation of the zincthiolate complex and uncoupling of endothelial nitric oxide synthase by peroxynitrite. J Clin Invest 109: 817-826, 2002.

213. Zweier JL, Samouilov A, and Kuppusamy P. Nonenzymatic nitric oxide synthesis in biological systems. Biochim Biophys Acta 1411: 250-262, 1999.
Address correspondence to:

Dr. Pasquale Pagliaro

Dipartimento di Scienze Cliniche e Biologiche

Università di Torino

Regione Gonzole 10

Orbassano (TO) 10043

Italy

E-mail: pasquale.pagliaro@unito.it

Date of first submission to ARS Central, April 10, 2010; date of final revised submission, July 12, 2010; date of acceptance, July 18, 2010.

\begin{tabular}{|c|}
\hline 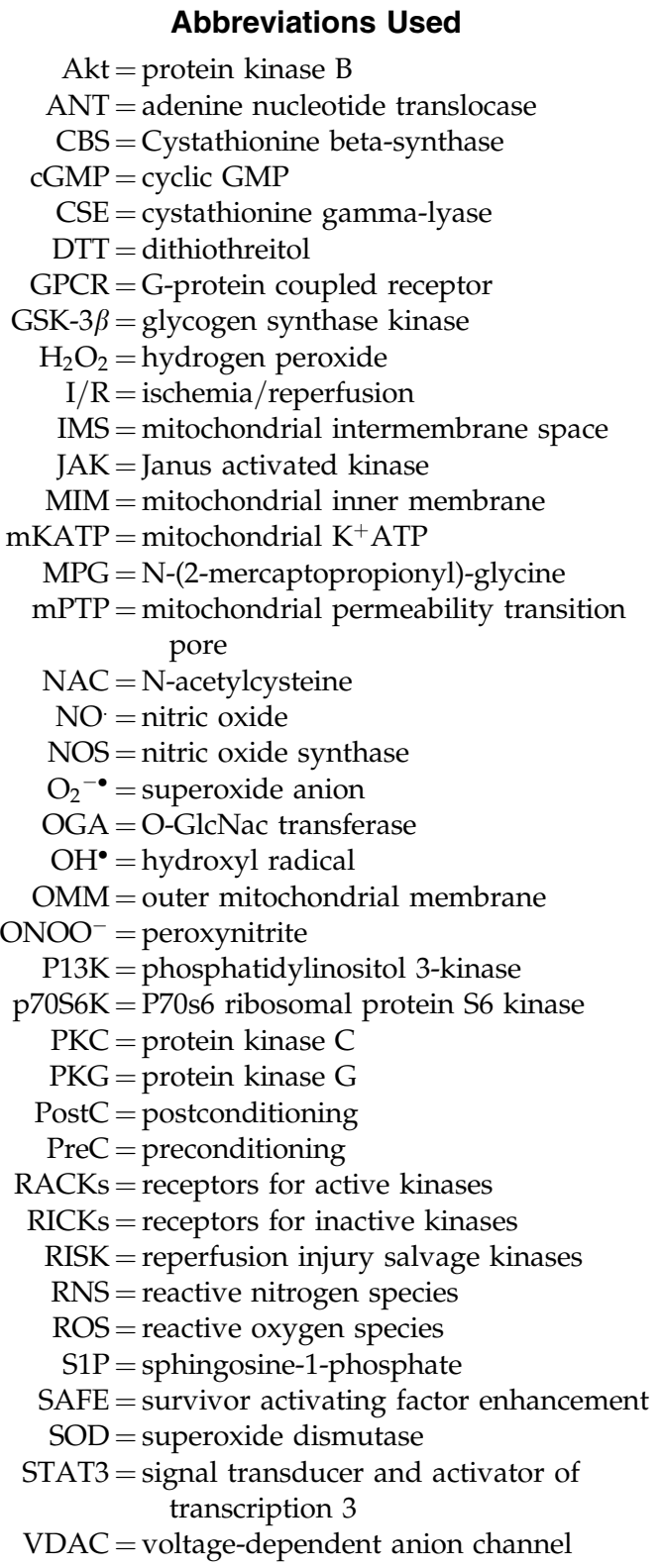 \\
\hline
\end{tabular}

